Rhode Island College

Digital Commons @ RIC

Master's Theses, Dissertations, Graduate

Master's Theses, Dissertations, Graduate Research and Major Papers Overview

Research and Major Papers

$12-1-2019$

\title{
The Effect of Anesthesia on the Developing Brain
}

Roy W. DeGrange

Follow this and additional works at: https://digitalcommons.ric.edu/etd

Part of the Nursing Commons

\section{Recommended Citation}

DeGrange, Roy W., "The Effect of Anesthesia on the Developing Brain" (2019). Master's Theses, Dissertations, Graduate Research and Major Papers Overview. 314.

https://digitalcommons.ric.edu/etd/314

This Major Paper is brought to you for free and open access by the Master's Theses, Dissertations, Graduate Research and Major Papers at Digital Commons @ RIC. It has been accepted for inclusion in Master's Theses, Dissertations, Graduate Research and Major Papers Overview by an authorized administrator of Digital Commons @ RIC. For more information, please contact digitalcommons@ric.edu. 



\title{
THE EFFECT OF ANESTHESIA ON
}

THE DEVELOPING BRAIN

\author{
A Major Paper Presented \\ by \\ Roy W. DeGrange, SRNA
}

Approved:

Committee Chairperson

(Date)

Committee Members

\begin{tabular}{l}
\hline (Date) \\
\hline (Date) \\
\hline (Date)
\end{tabular}

Dean, School of Nursing 


\section{THE EFFECT OF ANESTHESIA ON THE DEVELOPING BRAIN}

by

Roy W. DeGrange, SRNA

A Major Paper Submitted in Partial Fulfillment

of the Requirements for the Degree of

Master of Science in Nursing

in

The School of Nursing

Rhode Island College

2019 


\begin{abstract}
Damage caused by administering general anesthetics to the developing brain in young children and pregnant mothers is of concern among practicing anesthesia providers. Studies using young rodents and non-human primates have shown that animals are susceptible to neurodegeneration when exposed to high concentrations of general anesthesia. Randomized control trials using rodents as subjects used behavioral and histological experiments to determine the adverse effects of general anesthetics including the inhalation agents desflurane, isoflurane, and sevoflurane in addition to intravenous ketamine. The purpose of this systematic review was to examine the current literature to determine the effects these anesthetics pose on rodent subjects and how that translates into the human population. This systematic review was constructed using both PRISMA and ARRIVE as guidelines. A literature review was conducted and data was collected from each study. A cross-study analysis was created through data collected from each study by the author of this systematic review. The randomized control trials reviewed provide evidence that the types of inhalation and intravenous anesthesia agents studied can affect the developing brains of rodents. Anesthesia providers can use these results as a guide when administering anesthesia to infants, young children, and gravid mothers, however, more studies focusing on the long-term effects these agents have on children are warranted.
\end{abstract}




\section{Acknowledgments}

I'd like to thank all the professors who guided me through this MSN program most notably, Dr. Misto, who without her I would still be writing this paper. The program directors of Saint Joseph's School of Nurse Anesthesia, Dr. Anne Tierney, CRNA and Elena Litmanovich, CRNA who imparted their knowledge over the last thirty months. In addition, I would like to acknowledge my fellow SRNAs who were always there to add support academically and emotionally. Of course, last but not least, my family including my wife who sacrificed the most to put up with me during our little journey in Rhode Island. 


\section{Table of Contents}

Background/Statement of the Problem ............................................................ 1

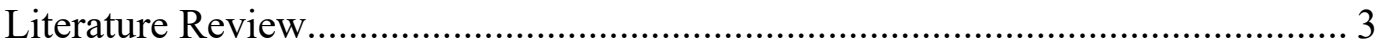

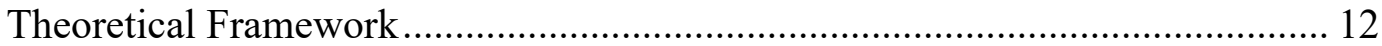

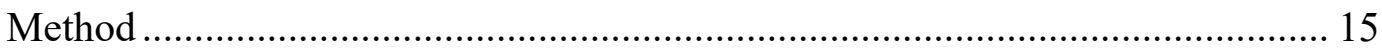

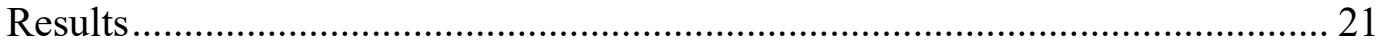

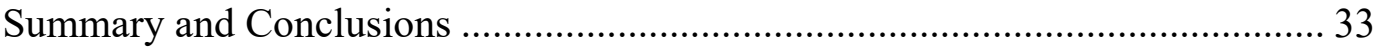

Recommendations and Implications for Advanced Nursing Practice ................. 38

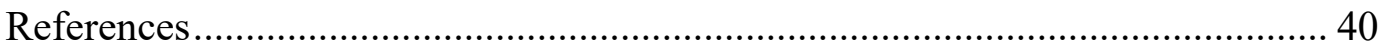

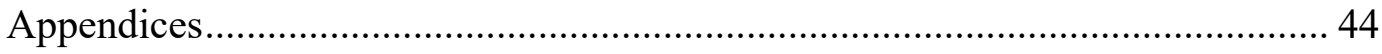




\section{THE EFFECT OF ANESTHESIA ON THE DEVELOPING BRAIN}

\section{Background/Statement of the Problem}

Potential damage caused by administering general anesthetics to the developing brain in young children and pregnant mothers is of grave concern among practicing anesthesia providers. Anesthetic agents and drugs could adversely affect the brain of children as it develops by possibly disrupting normal neuroapoptosis (Aker, Block \& Biddle, 2015). Neuroapoptosis is the body's normal controlled cell death that is crucial in the role of brain development (Aker et al., 2015). Controlled cell death plays a vital role in neurodevelopment and helps to limit redundancy, faulty neurons, or unused neurons from crowding the developing brain (Creely, 2016).

Anesthesia can disrupt this normal development by altering neuroapoptosis and increasing neurodegeneration, causing unwanted damage (Reddy, 2012). Studies using young rodents and non-human primates have shown that animals are susceptible to neurodegeneration when exposed to high concentrations of general anesthesia. This damage could cause learning delays, long term memory deficits, and spatial recognition impairment in the human population as well (Reddy, 2012). Additionally, studies that have examined infants and children exposed to large quantities of anesthetics have demonstrated increased difficulties in learning as well as more behavioral problems when compared to that of the general population of the same age (Reddy, 2012). There is currently, however, no available empirical evidence that describes how exposure to anesthesia in children under age four may lead to adverse effects on neurological development. Most of the current human research regarding anesthetic effects on the developing brain rely on retrospective studies, and existing databases, to review the long- 
term effects of anesthesia. Currently, studies such as the SMART Tots initiative are underway to explore how anesthesia affects human children and fetuses (Aker et al., 2015). Although there are significant expenses and ethical dilemmas to consider in the design of large-scale research in this topic area, future evidence from large randomized control trials (RCTs) such as the SMART Tots study will hopefully paint a clearer picture on how anesthesia affects human subjects as the brain develops (Aker et al., 2015).

As more and more gravid mothers and young children are undergoing general anesthesia for procedures, it is becoming vital to determine how anesthesia affects the developing brain. Studies that focus on inhalation agents, intravenous agents, and ways to protect the young brain are becoming more crucial. Knowledge generated from sound research is needed to determine the safest and most effective way to administer anesthesia to this vulnerable population.

The purpose of this systematic review was to determine the effects of general anesthesia on the developing brain of fetuses and children age four and under. This systematic review comprehensively reviewed literature that focus on how anesthetics affect the developing brain.

Next, a review of the literature will be presented. 


\section{Literature Review}

Potential damage caused by administering general anesthetics to the developing brain in young children and pregnant mothers is a hot topic among practicing anesthesia providers. This damage could cause learning delays, long term memory deficits, and spatial recognition impairment (Aker et al., 2015). In utero, the developing brain usually undergoes neuroapoptosis, defined as normal controlled cell death vital to brain development (Aker et al., 2015).

A literature search was completed using the keywords: "Brain development," "Anesthesia Effect on the Developing Brain," "Neuroapoptosis," and "Effects of Volatile Anesthetics." CINAHL and PubMed were used to locate relevant literature for evaluation. The literature search was limited to retrospective studies, random controlled trials (RCT), and systematic reviews no older than the year 2011.

\section{Fetal Brain Development}

Of all the human organ systems, the brain is the most complex. It is made up of over 100 billion information processing cells known as neurons (Stiles \& Jernigan, 2010). Neurons become created through the process of neurogenesis. These cells make up large networks that are responsible for thoughts, feelings, actions, and sensations (Stiles \& Jernigan). Early in fetal development, brain tissue derives from the ectoderm, which begins as a neural plate on day 16 of gestation; by day 21 this tissue forms a neural tube (Chudler, 2015). The neural tube splits into three separate areas, including the forebrain, midbrain, and hindbrain. In the $7^{\text {th }}$ week of development, the brain divides again through a process called encephalization, which increases the size and functionality of the brain. The majority of the brain development occurs during the prenatal period where the brain 
will increase by $260 \%$ during the third trimester (Rothbaum et al., 2015). Between the last trimester and age three, the human brain sustains rapid development. Neurogenesis will continue after birth in the postnatal period, but to a much lesser degree (Stiles \& Jernigan, 2010). Around 250,000 neurons are added every minute and become connected via synapses, a process known as synaptogenesis. By adult age, there are an estimated 60 trillion neuronal connections (Stiles \& Jernigan, 2010).

The physiologic processes of synaptogenesis, neurogenesis, and gliogenesis allow the neurons to mature and differentiate. Synaptogenesis depends on constant neuronal signaling, communication, and feedback processing to create meaningful neuronal connections. During these developments, an overproduction of neurons, synapses, glial cells, and neural processes occurs (Stiles \& Jernigan 2010). Neurons that are redundant or serve no purpose get pruned via neuroapoptosis.

In order for these physiologic processes of brain development to occur, proper nutrition of the mother is warranted. Adequate intake of vitamins and minerals help promote adequate brain development. For example, iron plays a part in neuronal myelination and development of the frontal lobe in infants (Young, 2012). Another prime example is the intake of vitamin B12, which plays an essential role in neurologic and sensory developments (Rothbaum, Aly, \& Massaro 2015). Without a balanced diet, a malnourished mother may produce children with smaller head circumference and lower brain weight which can contribute to an adverse neurodevelopmental outcome (Rothbaum et al., 2015).

The brain is also susceptible to outside environmental factors that can cause adverse outcomes during development. A mother exposed to such things as lead, 
mercury, and radiation exposure can result in reduced cognitive and motor skills in the child (Rothbaum et al., 2015). Lead, in particular, is known to injure developing neurons (Rothbaum et al., 2015). Drugs such as nicotine, alcohol, and cocaine ingested by the mother can be neurotoxic to the developing fetus resulting in lower intelligent quotient, developmental delays, and growth delays (Rothbaum et al., 2015).

Excessive alcohol intake by the mother can lead to fetal alcohol syndrome in the infant, resulting in many disorders causing intellectual and behavioral impairments. These disorders are known as fetal alcohol spectrum disorders characterized by a wide range of teratogenic and psychological defects that can result in non-hereditary mental delays depending upon the amount of alcohol consumption (Parker et al., 2014). Even a small amount of alcohol ingestion during pregnancy is known to contribute to cognitive and behavioral issues. These issues include mood disorders, aggression and addictive behavior by negatively affecting neuronal and central nervous system development in utero (Parker et al., 2014).

Animal studies are employed to ethically explore the effects of alcohol. For instance, Brocardo et al. (2017) studied Sprague Dawley rats exposed to ethanol during critical periods of brain development. The pregnant female rats separated into three cohorts represent their respective different trimesters. First-trimester pregnant rats (ETOH-1) were given a liquid diet in the first trimester which included $35.5 \%$ of their calories obtained from ethanol (Brocardo et al., 2017). Following the first trimester equivalent time, the ETOH-1 group ate a regular chow diet. Similarly, the second (ETOH-2) and third (ETOH-3) trimester rat groups received liquid foods containing 
alcohol in their respective trimester, and chow for the other trimesters. Blood alcohol levels were also monitored throughout the pregnancy (Brocardo et al., 2017).

The rat pups were sacrificed to examine the effects the ethanol had on brain tissue. It was found that oxidative damage was caused to the hippocampus of the ethanolexposed rat pups which contributes to developmental delays (Brocardo et al., 2017). There was also a decrease in the endogenous antioxidant glutathione levels in the hippocampus and cerebellum when exposed to EtOH. A two-way analysis of variance (ANOVA) revealed the effects of a developmental condition and period of exposure to alcohol as a significant interaction $(F(2,70)=9.56, p<0.01)$ (Broccardo et al., 2017). Analysis revealed total glutathione levels were significantly reduced in the ETOH-1 group when compared to their controls $(p<0.01)$ within the hippocampus regions of CA and PFC (Brocardo et al., 2017). Glutathione reduction is known to affect synaptic plasticity (Brocardo et al., 2017). Synaptic plasticity is the ability for synapses to weaken or strengthen and are vital to memory formation (Brocardo et al., 2017). The results of this study indicate that there is no safe time in pregnancy to ingest alcohol, and by doing so can cause long-term alterations in brain function associated with fetal alcohol spectrum disorders (Brocardo, et al., 2017).

The brain of the fetus is noted to be very fragile as it develops. It is susceptible to many outside influences and requires well-balanced nutrition by the mother. When exposed to teratogens such as drugs, environmental agents, and alcohol, neurotoxicity to the brain can occur leading to abnormal neuronal development and later cognitive delays. 


\section{Neurotoxicity}

Neurotoxicity is a biological or chemical agent causing toxicity to the peripheral or central nervous system. It defines any adverse effect on the chemistry structure or function of the nervous system, during development or at maturity, induced by chemical or physical influences (Giordano \& Costa, 2012). It is also categorized by reversible and irreversible brain damage, which could lead to neurocognitive deficits (Vilsides \& Xie, 2012). Neurotoxicity can cause changes in neurons (neuronopathy), axon degeneration, and the loss of glial cells around the axon (myelinopathy) (Giordano \& Costa, 2012). There are over 200 well-established chemicals that are neurotoxic to humans, including mercury, lead, and organophosphates, that can be neurotoxic to the fetus in utero (Giordano \& Costa, 2012). Exposure to these chemicals prenatally and early postnatally possesses damaging influences on the structure of the nervous system (Giordano \& Costa, 2012). These influences can lead to cognitive disabilities including learning disabilities and developmental delays.

Neurotoxicity related to Anesthesia. Anesthesia is known to cause neurotoxicity in some populations, particularly children and the elderly (Vilsides \& Xie, 2012). Inhalation and intravenous anesthetics have been shown to cause neuroapoptosis, caspase activation, $\beta$-amyloid protein accumulation, and neurodegeneration in animals that can lead to cognitive defects (Vilsides \& Xie, 2012). Drugs used in anesthesia can adversely affect neurotransmitters and receptors that are vital to brain development. This neurotoxic insult can disrupt brain development contributing to cognitive and behavior issues later in children exposed to anesthesia (Creeley, 2016). The importance of these receptors will be explored further in the discussion of neuroapoptosis. 


\section{Neuroapoptosis}

Apoptosis is a physiological process that targets cells to be phagocytized by macrophages in what is known as programmed cell death (Aker, Block, \& Biddle, 2015). The mechanism of apoptosis can be categorized into four distinct phases: signaling, control and regulation, execution, and removal of the dead cell (Bennetts \& Pierce, 2010). The first phase, signaling, begins through a stimulus caused by tumor necrosis factor that triggers the apoptotic pathway, starting programmed cell death. The second control, and regulation, phase determines whether to commit or abort, apoptosis. If committed during this step there is no turning back. During the third stage of execution, the cell begins to break apart by proteolytic caspases. In the final stage, the cell is removed through phagocytosis by macrophages (Bennetts \& Pierce, 2010).

Neuroapoptosis is programmed cell death that is used to help control neuronal development. During neuroapoptosis, $50-70 \%$ of the excess neurons and synapses produced become phagocytized. The brain contains receptors, such as N-methyl-Daspartate (NMDA) and $\gamma$-aminobutyric acid $\left(\mathrm{GABA}_{\mathrm{A}}\right)$ that are vital to normal neuronal development (Aker, Block, \& Biddle, 2015). N-methyl-D-aspartate, an excitatory neurotransmitter, plays a significant role in learning and memory formation. During early brain development, the major inhibitory neurotransmitter GABA is also excitatory. This neurotransmitter is vital for neurogenesis and neuronal proliferation (Wu \& Sun, 2015). During this critical time of development, the brain's receptors are susceptible to outside influences. Drugs, alcohol, and medications, such as those used in modern anesthesia, can disrupt the programmed cell death of neuroapoptosis. If the errant neurons are not pruned adequately via neuroapoptosis, long-term cognitive disability and brain malformation 
could occur causing a lifetime of intellectual disability that includes both cognitive and behavioral effects (Creeley, 2016).

Wilder et al. (2009) conducted a retrospective study to examine the long-term effects of anesthesia on children and learning disabilities. The authors hypothesized that similar to how alcohol exposure can cause changes in the developing brain, anesthesia may also contribute to adverse changes. The study included 5,357 children; of which 593 of the children exposed to anesthesia before age four. Investigators found that for those who had a single exposure to anesthesia $(n=449)$ it did not increase their chance of developing a learning disability (adjusted hazard ratio 1.00; 95\% CI, $0.79-1.27$ ). However, those $(n=144)$ that were exposed to two anesthetics (adjusted hazard ratio 1.59; $95 \% \mathrm{CI}, 1.06-2.37$ ) or to three or more anesthetics (adjusted hazard ratio $2.60 ; 95 \% \mathrm{CI}$, 1.60-4.24) significantly increased their risk factor $(p<0.001)$ for developing a learning disability. These risk factors include deficiencies in reading, writing, and mathematics (Wilder et al., 2009). Additionally, the estimated risk increased from $20 \%$ to $35 \%$ for development of a learning disability by age 19 in those children exposed to multiple doses of anesthesia versus children without anesthesia exposure (Wilder et al., 2009). The authors concluded that multiple exposures to general anesthesia could lead to learning disabilities caused by impairment of neural development.

\section{Anesthesia: Overview}

Anesthesia is defined as insensitivity to pain, especially as artificially induced by the administration of gases or the injection of intravenous drugs before surgical operations (Butterworth, Mackey, \& Wasnick, 2014). The term anesthesia was first used by the Greek philosopher Dioscorides to describe narcotic-like effects caused by the plant 
mandragora (Butterworth, Mackey, \& Wasnick, 2014). Later the term was used by Oliver Wendell Holmes to include a state of amnesia, analgesia, and narcosis to make pain free surgery possible (Butterworth et al., 2014). There are several types of anesthetics including inhalation anesthetics and intravenous anesthetics that combine to make up general anesthesia. General anesthesia uses a combination of drugs to produce a loss of consciousness. The combination of drugs causes muscle relaxation, analgesia, and amnesia to safely and effectively allow patients to withstand surgical procedures.

Inhalation agents. Inhalation anesthesia was the first type of anesthesia used for surgery in the 1800 s before the invention of the hypodermic needle. WTG Morton demonstrated the use of diethyl ether as the first general anesthetic in 1846 (Butterworth et al., 2014). Diethyl ether is the precursor to modern volatile inhalation anesthetics such as nitrous oxide, sevoflurane, desflurane, and isoflurane. These current gases are liquid at room temperature, allowing them to transport easily and are relatively cheap to manufacture. With the help of a vaporizer, these liquids evaporate quickly, making them ideal as an anesthetic gas. All of the volatile inhalation agents act on inhibitory neurotransmitters known as $\mathrm{GABA}_{\mathrm{A}}$ receptors in the brain (Garcia, Kolesky, \& Jenkins, 2010). Nitrous oxide sometimes referred to as "laughing gas," is a non-volatile anesthetic gas stored and administered from a gas cylinder. Nitrous oxide differentiates itself from other inhalation anesthetics in that it acts on NMDA receptors (Garcia et al., 2010).

Intravenous agents. As the science of anesthesia has progressed, innovative types of administration developed as well. The use of intravenous medications was first introduced as a type of anesthetic in 1872 using the sedative Chloral Hydrate by Pierre Ore' (Butterworth et al., 2014). Drugs such as morphine, barbiturates, and 
sedative/hypnotics are used today in many surgeries requiring anesthesia. These drugs can be used in combination with inhalation agents, or on their own as part of general anesthesia.

One of the most common hypnotic intravenous anesthetic drugs is propofol. Propofol, when used for sedation, contains some amnestic properties. Its main effect is on that of $\mathrm{GABA}_{\mathrm{A}}$, a vital neurotransmitter to neurodevelopment, on the brain. $\mathrm{GABA}_{\mathrm{A}}$ is the principal inhibitory neurotransmitter in the brain that propofol interacts with causing disassociation resulting in unconsciousness and retrograde amnesia (Shafer, Rathmell, \& Flood, 2015). Intravenous anesthesia medications such as propofol have been found to adversely affect the developing brain in animals (Andropoulos, 2017). Some evidence suggests that specific intravenous anesthetic exposure in the developing fetus, and children, may alter the GABA receptors placing them at risk for neurodegenerative changes (Andropoulos, 2017).

There are additionally, adjunct intravenous medications used during general anesthesia including benzodiazepines such as, midazolam, diazepam, and lorazepam which have sedative effects that target GABA receptors (Garcia et al., 2010). Another of the commonly used intravenous anesthetics, Ketamine, alters the NMDA memory receptors which contribute to its anesthetic effects.

One of the earliest studies focusing on the blockade of the NMDA receptor was completed by Ikonimidou (1999). The purpose of this study was to determine if the blocking of NMDA receptors in parturient mothers, when exposed to certain anesthetic agents, affected the neuronal development of the fetus or neonate. Ikonimidou (1999) studied seven-day-old rat pups exposed to phencyclidine (PCP), carboxy pierazin-4-yl- 
propyl-2-phosphoric acid (CPP), and Ketamine. The rat pups were exposed to a steady state of each of these drugs over 8 hours (Ikonimidou, 1999). After sacrificing the rats, the authors used electron microscopy of the tissues to find that the exposure caused cell degeneration in the rats by altering neuroapoptosis (Ikonimidou, 1999). These findings suggest that fetuses and infants exposed to Ketamine and Nitrous Oxide during anesthesia could be at risk for neurodegeneration of the developing brain.

In summary, the concern that neurotoxicity of general anesthesia to the developing brains of infants and fetuses continues to be a pressing issue among providers. Evidence through animal trials and retrospective studies shows a potential detriment to this vulnerable patient population. As the surgical interventions on this population increase the number of research increases.

Next, the discussion of the theoretical framework. 


\section{Theoretical Framework}

Nursing is a profession that uses many different theoretical approaches to guide nursing practice. One such theorist, Betty Neuman, is known for The Neuman Systems Model of Nursing. While working on her education, she developed her model while lecturing at UCLA. "A Model for Teaching the Total Person Approach to Patient Problems" was first published in 1972 and would soon develop into "The Neuman Systems Model" used by nursing programs around the world (McEwen \& Wills, 2014).

In Neuman's System, humans are described as a composite of interacting variables; physiological, psychological, sociocultural, developmental, and spiritual. These variables promote homeostasis. Neuman's version of homeostasis describes a structure of concentric rings, which represent three environments; internal, external, and created, all of which may help a person adapt to stressors (McEwen \& Wills 2014, p. 152). Neuman describes the stressors as intra, inter, and extra personal in nature. Intrapersonal stressors happen internally, for example, infection, thoughts, and feelings. Interpersonal stressors occur from an individual's interaction with surrounding people. Extra personal stressors arise outside of the individual and include such examples as finances and jobs. Lines of defense are set up around an underlying structure or central core of a person to protect from these stressors. These basic structures, which are common to all organisms, are normal temperature range, genetic structure, response pattern, organ strength or weakness, and ego structure (McEwen \& Wills 2014, p. 152).

Neuman terms the first line of defense as the Flexible Line of Defense. This outer line of the defense protects the human being from stressors. The second line of defense is the Normal Line of Defense which adapts over time to keep the person in reasonable 
health. The final line of defense or Lines of Resistance, such as a person's immune system, stabilizes the person back into wellness (Neuman \& Fawcett, 2009). These defenses protect a person from environmental factors and stressors, in turn, maintaining wellness using a method of constant adaptation.

Another concept Neuman includes in the theory is prevention: primary, secondary, and tertiary prevention. Primary prevention is the use of knowledge to reduce the effects of environmental factors before causing a reaction. Secondary prevention studies symptoms following exposure to stressors and uses interventions to decrease the possible effects while tertiary prevention uses an adjustive process and maintenance factors to return the person to a state of primary prevention.

The Neuman Systems Model can apply to how anesthesia affects the developing brain. During procedures requiring anesthesia, the lines of defense are penetrated causing detriment to the developing brain. This environmental factor creates an extra personal stressor the body was not prepared to undergo. Once in the system, the anesthesia becomes an intrapersonal stressor, which could cause neurotoxicity leading to cognitive impairment. If cognitive impairment occurs from this invasion, other stressors can develop.

Neuman's primary prevention concept is the best defense against adverse effects of anesthesia on the developing brain. Primary prevention is used to reduce risk factors for patients before the start of treatments. With increased knowledge of how anesthesia contributes to cognitive impairment, research and trials can determine which modalities of anesthesia cause the least amount of damage. Once established the treatment plan can be used in vulnerable populations protecting the brain from impairment before it occurs. 
Even though Neuman's Systems model isn't very parsimonious, it can be shaped to a variety of nursing situations whether it is how extra personal stressors wreak havoc on a patient's diabetes or how anesthesia affects the developing brain the model can determine how to reduce these stressors maintaining wellness in an individual.

Next, the Methods will be discussed 


\section{Method}

\section{Purpose}

The purpose of this systematic review was to determine the potential adverse effects of anesthesia on the developing brain in an unborn human fetus and infant. This review considers the following question: In children and fetuses of mothers undergoing general anesthesia, what are the adverse effects of the perioperative medications on the developing brain?

\section{Search Strategy}

The literature search was conducted using the CINAHL and PubMed online databases simultaneously. The search term used was "effects of anesthesia," which yielded over 100,000 hits. By using the terms "effects of anesthesia on the developing brain" in the search engine results narrowed to 243 articles. The level of evidence and pertinence determined the number of articles used, based on inclusion and exclusion criteria listed below. Preferred Reporting Items for Systematic Reviews and MetaAnalyses (PRISMA) was developed and finalized in 2009 as a critical appraisal tool to help authors develop systematic reviews (Moher, 2009). This critical appraisal tool includes a checklist 27-item checklist and a four-phase flow diagram utilized to minimize bias, provide reliable findings, and allow accurate conclusions to be drawn from the collection of studies reviewed. Examples of the original checklist and flow diagrams can be found in Appendix A. Articles meeting the criteria were evaluated using the PRISMA flow diagram located in the results section for inclusion eligibility. 


\section{Inclusion Criteria}

The literature search articles will be evaluated by relevance according to the purpose, intervention, and outcomes (PIO) design. The inclusion criteria will focus on studies containing randomized clinical control trials conducted within the last ten years. The clinical control trials will focus on the effects of anesthesia administered to young rats and mice to evaluate the impact on the developing brains of the human population.

\section{Exclusion Criteria}

Exclusion criteria consisted of non-English written articles and articles older than ten years. Subjective non-scientific articles were also dismissed.

\section{Data Collection}

The articles reviewed determined useful and relevant data. Data collected included results from randomized control trials using primarily animal models such as rodents. The effects of anesthesia on rodent models were classified and organized using two tables. The second table consists of data collection, results, limitations and conclusions.

Table 1

Data Collection Tool 1

\begin{tabular}{|l|l|l|l|l|}
\hline Purpose & Study Design & Subject Demographics & Methods & Measurement \\
\hline & & & & \\
\hline & & & & \\
\hline & & & & \\
\hline & & & & \\
\hline
\end{tabular}


Table 2

Data Collection Tool 2

\begin{tabular}{|l|l|l|l|}
\hline Data Analysis & Results & Limitations & Conclusions \\
\hline & & & \\
\hline & & & \\
\hline & & & \\
\hline & & & \\
\hline
\end{tabular}

Outcomes specific to the effect on cognitive development after anesthesia was the primary data collected. The articles focused on how intravenous and volatile gas anesthetics affect the brain as the child develops in and out of the womb. The articles explored cognitive defects such as memory and spatial reasoning by studying animals, particularly rodents, using random control trials and real-time studies on rat pups exposed to the anesthesia agents. The information gathered from these articles was used to form results indicating the best type of anesthesia to use for fetuses and young children, and what can be done to avoid any adverse effects of anesthesia during surgery.

\section{Data Synthesis and Cross Study Analysis}

The data collection tools created were used to gather information from the 
randomized control trials examined in this systematic review. A cross study analysis was then performed through creation of a comparison table that evaluated the studies by Behavioral Analysis Results, Histological Study Results, and Neurodegeneration Results. Data was then depicted in the table below (Table 3) with results described later in this systematic review (Appendix E).

Table 3

\begin{tabular}{|l|l|l|l|}
\hline Author/Year/Anesthetic & $\begin{array}{l}\text { Behavioral Analysis } \\
\text { Results }\end{array}$ & $\begin{array}{l}\text { Histological Study } \\
\text { Results }\end{array}$ & Neurodegeneration Results \\
\hline & & & \\
\hline & & & \\
& & & \\
\hline
\end{tabular}

\section{Critical Appraisal}

The Animals in Research: Reporting In Vivo Experiments (ARRIVE) guidelines for Randomized Control Trials, which is specific to animal studies was used to verify the relevance, integrity, and results of the articles utilized in this review. Each article was reviewed individually using the ARRIVE questionnaire checklist specific to animal research studies. The ARRIVE guidelines consist of a checklist of 20 items describing the minimum information that all scientific publications reporting research using animals should include (Kilkenny et al., 2010). Table 4, included below shows the ARRIVE grading system used to evaluate the studies reviewed. 
Table 4

\section{Arrive Grading System}

Item \#

\section{Recommendation}

\begin{tabular}{|c|c|c|c|}
\hline Title & 1 & $\begin{array}{l}\text { Provide as accurate and concise a description of the content of the article as } \\
\text { possible. }\end{array}$ & $\begin{array}{l}0=\text { inaccurate } \\
1=\text { accurate }\end{array}$ \\
\hline Abstract & 2 & $\begin{array}{l}\text { Provide an accurate summary of the background, research objectives, including } \\
\text { details of the species or strain of animal used, key methods, principal findings and } \\
\text { conclusions of the study. }\end{array}$ & $\begin{array}{l}0=\text { inaccurate } \\
1=\text { accurate }\end{array}$ \\
\hline Background & 3 & $\begin{array}{l}\text { a. Include sufficient scientific background } \\
\text { to understand the motivation and context for the study and explain the } \\
\text { experimental approach and rationale. } \\
\text { b. Explain how and why the animal species and model being used can address } \\
\text { the scientific objectives and, where appropriate, the study's relevance to } \\
\text { human biology. }\end{array}$ & $\begin{array}{l}0=\text { sufficient } \\
1=\text { insufficient }\end{array}$ \\
\hline Objectives & 4 & $\begin{array}{l}\text { Clearly describe the primary and any secondary objectives of the study, or } \\
\text { specific hypotheses beingtested. }\end{array}$ & $\begin{array}{l}0=\text { Clear } \\
1=\text { Not Clear }\end{array}$ \\
\hline \multicolumn{4}{|l|}{ Methods } \\
\hline $\begin{array}{l}\text { Ethical } \\
\text { statement }\end{array}$ & 5 & $\begin{array}{l}\text { Indicate the nature of the ethical review permissions, relevant licences and } \\
\text { national or institutional guidelines for the care and use of animals, that cover the } \\
\text { research. }\end{array}$ & $\begin{array}{l}0=\text { Clear } \\
1=\text { Not Clear }\end{array}$ \\
\hline Study design & 6 & $\begin{array}{l}\text { For each experiment, give brief details of the study design including: } \\
\text {-The number of experimental and control groups. } \\
\text {-Any steps taken to minimise the effects of subjective bias when allocating } \\
\text { animals to treatment (e.g. randomisation procedure) and when assessing results } \\
\text { (e.g. if done, describe who was blinded and when). } \\
\text {-The experimental unit (e.g. a single animal, group or cage of animals). }\end{array}$ & $\begin{array}{l}0=\text { Clear } \\
1=\text { Not Clear }\end{array}$ \\
\hline $\begin{array}{l}\text { Experimental } \\
\text { Procedures }\end{array}$ & 7 & $\begin{array}{l}\text { For each experiment and each experimental group, including controls, provide } \\
\text { precise details of all procedures carried out. }\end{array}$ & $\begin{array}{l}0=\text { Clear } \\
1=\text { Not Clear }\end{array}$ \\
\hline $\begin{array}{l}\text { Experimental } \\
\text { Animals }\end{array}$ & 8 & $\begin{array}{l}\text { Provide details of the animals used, including species, strain, sex, developmental } \\
\text { stage, and weight. }\end{array}$ & $\begin{array}{l}0=\text { Clear } \\
1=\text { Not Clear }\end{array}$ \\
\hline $\begin{array}{l}\text { Housing and } \\
\text { Husbandry }\end{array}$ & 9 & $\begin{array}{l}\text { Housing: type } \\
\text { Husbandry: breeding, light/dark cycles, temperature, etc. }\end{array}$ & $\begin{array}{l}0=\text { Clear } \\
1=\text { Not Clear }\end{array}$ \\
\hline Sample size & 10 & Number of animals used in each experiment. & $\begin{array}{l}0=\text { Clear } \\
1=\text { Not Clear }\end{array}$ \\
\hline $\begin{array}{l}\text { Animal Group } \\
\text { Allocations }\end{array}$ & 11 & $\begin{array}{l}\text {-Give full details of how animals were allocated to experimental groups, } \\
\text { including randomisation or matching if done. } \\
\text {-Describe the order in which the animals in the different experimental } \\
\text { groups were treated and assessed. }\end{array}$ & $\begin{array}{l}0=\text { Clear } \\
1=\text { Not Clear }\end{array}$ \\
\hline $\begin{array}{l}\text { Experimental } \\
\text { outcomes }\end{array}$ & 12 & $\begin{array}{l}\text { Clearly define the primary and secondary experimental outcomes assessed (e.g. } \\
\text { cell death, molecular markers, behavioral changes). }\end{array}$ & $\begin{array}{l}0=\text { Clear } \\
1=\text { Not Clear }\end{array}$ \\
\hline
\end{tabular}




\begin{tabular}{|c|c|c|c|}
\hline $\begin{array}{l}\text { Statistical } \\
\text { methods }\end{array}$ & 13 & $\begin{array}{l}\text {-Provide details of the statistical methods used for each analysis. } \\
\text {-Specify the unit of analysis for each dataset (e.g. single animal, group of } \\
\text { animals, single neuron). } \\
\text {-Describe any methods used to assess whether the data met the assumptions } \\
\text { of the statistical approach. }\end{array}$ & $\begin{array}{l}0=\text { Clear } \\
1=\text { Not Clear }\end{array}$ \\
\hline Baseline data & 14 & $\begin{array}{l}\text { For each experimental group, report relevant characteristics and health status of } \\
\text { animals (e.g. weight, microbiological status, and drug or test naïve) prior to } \\
\text { treatment or testing. (This information can often be tabulated). }\end{array}$ & $\begin{array}{l}0=\text { Clear } \\
1=\text { Not Clear }\end{array}$ \\
\hline $\begin{array}{l}\text { Numbers } \\
\text { analyzed }\end{array}$ & 15 & $\begin{array}{l}\text {-Report the number of animals in each group included in each analysis. } \\
\text { Report absolute numbers }\left(\text { e.g. } 10 / 20 \text {, not } 50 \%^{2}\right) \text {. } \\
\text {-If any animals or data were not included in the analysis, explain why. }\end{array}$ & $\begin{array}{l}0=\text { Clear } \\
1=\text { Not Clear }\end{array}$ \\
\hline $\begin{array}{l}\text { Outcomes \& } \\
\text { estimation }\end{array}$ & 16 & $\begin{array}{l}\text { Report the results for each analysis carried out, with a measure of precision } \\
\text { (confidence interval). }\end{array}$ & $\begin{array}{l}0=\text { Clear } \\
1=\text { Not Clear }\end{array}$ \\
\hline Adverse events & 17 & $\begin{array}{l}\text {-Give details of important adverse events in each experimental group. } \\
\text {-Describe any modifications to the experimental protocols made to reduce } \\
\text { adverse events. }\end{array}$ & $\begin{array}{l}0=\text { Clear } \\
1=\text { Not Clear }\end{array}$ \\
\hline $\begin{array}{l}\text { Interpretation/ } \\
\text { scientific } \\
\text { implications }\end{array}$ & 18 & $\begin{array}{l}\text {-Interpret the results, taking into account, the study objectives and } \\
\text { hypotheses, current theory and other relevant studies in the literature. } \\
\text {-Comment on the study limitations including any potential sources of bias, any } \\
\text { limitations of the animal model, and the imprecision associated with the results. } \\
\text {-Describe any implications of your experimental methods or findings for the } \\
\text { replacement, refinement or reduction (the } 3 \text { Rs) of the use of animals in research. }\end{array}$ & $\begin{array}{l}0=\text { Clear } \\
1=\text { Not Clear }\end{array}$ \\
\hline $\begin{array}{l}\text { Generalizability/ } \\
\text { translation }\end{array}$ & 19 & $\begin{array}{l}\text { Comment on whether, and how, the findings of this study are likely to translate } \\
\text { to other species or systems, including any relevance to human biology. }\end{array}$ & $\begin{array}{l}0=\text { Clear } \\
1=\text { Not Clear }\end{array}$ \\
\hline Funding & 20 & $\begin{array}{l}\text { List all funding sources (including grant number) and the role of the funder(s) in } \\
\text { thestudy. }\end{array}$ & $\begin{array}{l}0=\text { Clear } \\
1=\text { Not Clear }\end{array}$ \\
\hline
\end{tabular}

\section{Next is a discussion of the Results}




\section{Results}

\section{Prism Flow Diagram}

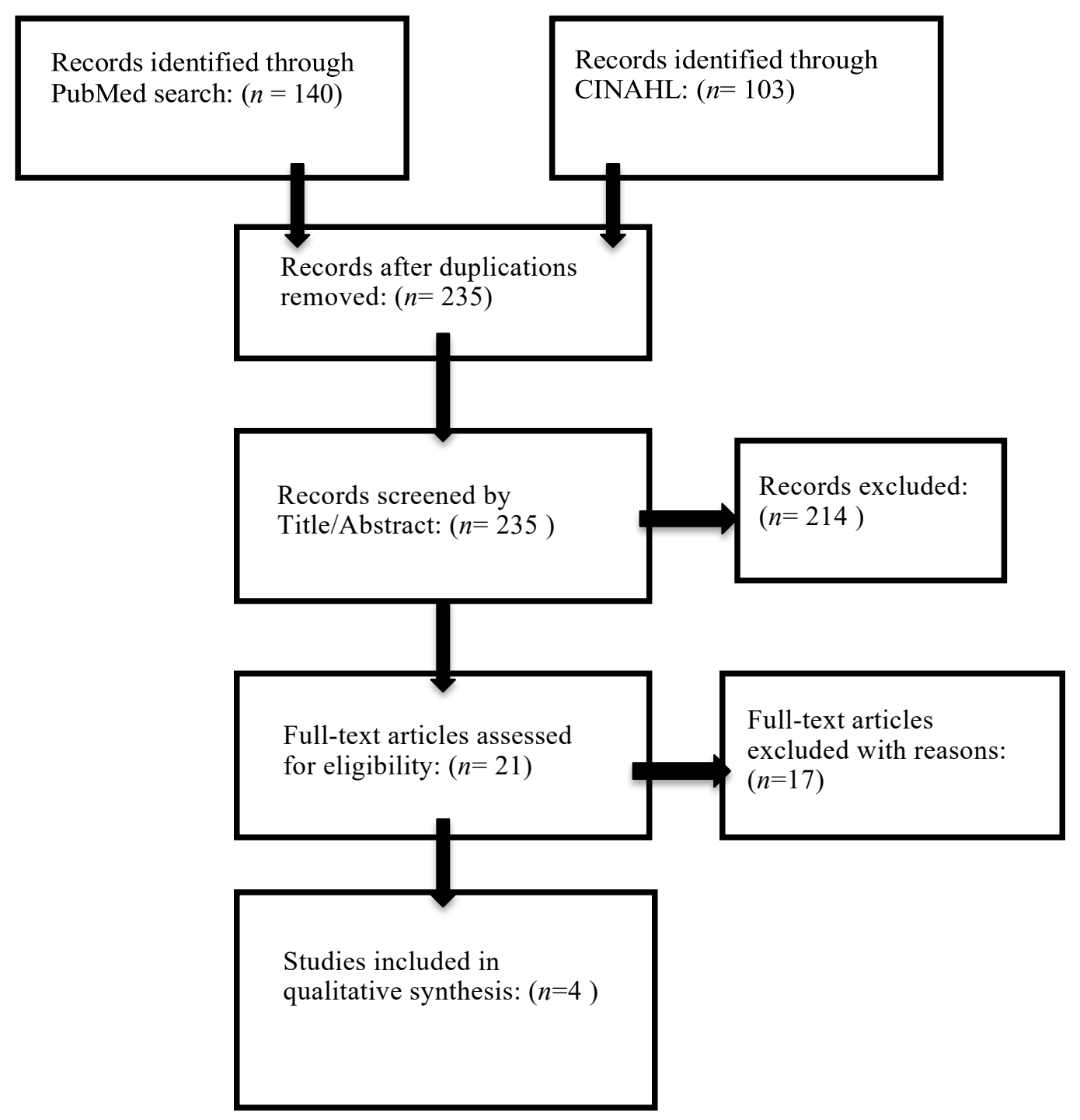

The PRISMA flowchart above, along with the inclusion and exclusion criteria discussed in the methods section were used to narrow down, and ultimately determine articles appropriate for the systematic review. A total of eight articles were determined to be duplicated in both databases and were discarded. After reviewing the titles and abstracts further elimination of articles occurred using the previously stated exclusion 
criteria. This ultimately brought the total number of articles to 21 . The study articles were further narrowed down to four in total by using both exclusion and inclusion criteria. The exclusion criteria consisted of non-English written articles, articles older than ten years, and subjective non-scientific articles, while the inclusion criteria encompassed randomized control trials.

O’Farrell, Foley, Bugger, \& Gallagher (2018) conducted a randomized control trial using 15-day old Wistar rat pups to evaluate the neurotoxic effects of inhalation agents. This experimental study exposed the rats to urethane, isoflurane and sevoflurane (Note: Urethane was admitted as an outcome criteria in this systematic review, as it is not currently being used as an anesthetic in humans). All animals were administered either the anesthetic or a placebo (O'Farrell et al., 2018). The rats were then tested at 48 hours and 96 hours for behavioral and histological analysis (Appendix B, table B-1).

O'Farrell et al. (2018) determined that in rats exposed to the volatile anesthetic gases: sevoflurane and isoflurane, demonstrated enhanced excitability through a number of behavioral parameters. The behavioral parameters observed included activity, grooming, rearing, and suckling (O'Farrell et al., 2018). Activity and locomotion included observation on how much each subject moved in an enclosed activity box. The activity parameters were averaged based on the time the animal spent moving and the percent of time active (O'Farrell et al., 2018). Grooming and rearing behavioral parameters included comparisons of how much time the mother would groom and spend time with the rat pup after anesthesia exposure versus a control group. The suckling score was calculated by monitoring the time the rat pups spent feeding on their mother 
(O'Farrell et al., 2018). By observing these behaviors in the rat pups exposed to sevoflurane and isoflurane, versus a control group, researchers could determine if any insults to the brain occurred. The observations took place at 48 and 96 hours post exposure.

Results related to animal behavior were reviewed at 48 and 96 hours (Appendix C, Table C-1). At 48 hours post exposure there was little clinical difference found in the activity parameter in the sevoflurane and isoflurane exposed animals, when compared to the control. Scores of $11.7+/-2.7$ were awarded for sevoflurane and $9.38+/-3.21$ for isoflurane versus the control score of $9.9+/-1.66$ with a $p$ value of 0.03 . However, there was a notable increase at 96 hours post exposure (O’Farrell et al., 2018). With sevoflurane scoring $15.8+/-1.56$ and Isoflurane scoring $15.4+/-2.03$ versus the control group at a score of $11.2(p=0.02)$ (O’Farrell et al., 2018). Suckling scores for the sevoflurane group were significantly decreased at 48 hours $1.67+/-0.33$ compared to the control group of 3.20 +/- 0.53 (O’Farrell et al., 2018). At 96 hours Sevoflurane continued to decrease to $0.89+/-0.26$ versus the control groups score of $2.42+/-0.36$ (O'Farrell et al., 2018). Isoflurane exposed rats only saw a significant decrease in suckling scores of $1.13+/-0.23$ at 96 hours when compared to the control group (O'Farrell et al., 2018). Rearing scores for sevoflurane $(1.67+/-0.33)$ exposed rats decreased compared to controls $(3.20+/-0.53)$, whereas the isoflurane group $(2.63+/-0.37)$ demonstrated little difference compared to the baseline control group $(p=0.04)$ (O'Farrell et al., 2018).

O'Farrell et al. (2018) also evaluated histological studies, such as total cell counts located in the piriform cortex of the volatile anesthetic exposed rats (Appendix C, Table C-1). By counting the number of dying cells in this cortex, O'Farrell et al. determined the 
amount of neurodegeneration that occurred in the brain tissue of the exposed rats. Again, using the time of 48 hours post exposure and 96 hours post exposure, harvested brain tissue was examined to count the total cells present in the layers of the piriform cortex.

Total cell counts were calculated in layer II of the piriform cortex for each of the rats exposed to volatile anesthetics (O'Farrell et al., 2018). A mean +/- SEM value was calculated for each exposed group (O'Farrell et al., 2018). At the 48-hour time point both the isoflurane and sevoflurane group $(p=0.03)$ demonstrated an increase in total apoptic cells in comparison to the control group. There was no significant change between the sevoflurane group when compared to the control group at 96 hours (O'Farrell et al., 2018). Isoflurane had a significant reduction in total cells in the brain at 96 hours post exposure ( $p=0.03)$ (O'Farrell et al., 2018). The results in this study demonstrated that isoflurane damaged a larger amount of tissue leading to neurotoxicity, resulting in more harm than sevoflurane to the developing brain.

Using the ARRIVE guidelines it was determined that O'Farrell et al. (2018) lacked a clear ethical statement from the authors. Funding of the study also was not disclosed. Furthermore, the paper also failed to divulge details on the how the rats were housed during the experiments. Deficiencies in these categories resulted in a score of zero.

Tao et al. (2016) aimed to determine if isoflurane or desflurane caused more harm to the developing brain by creating a randomized control trial using three groups of 119 six-day-old mice: a control group, isoflurane group, and a desflurane group (Appendix B, Table B-2). After being subjected to their respective anesthetic groups the mice were 
placed in two experiments in addition to brain harvesting to determine the effects of the anesthetics, isoflurane and desflurane, on spatial reasoning and memory. The mice were divided equally among the litters to minimize differences associated with different mothers. Mice that had been exposed to these volatile gases were put through learning and memory condition testing including the Morris water maze (MWM) and a fear conditioning test (FCT) (Tao et al., 2016). Prior to volatile gas exposure the MWM trials mice were placed in a small pool and investigators determined how fast it took them to reach a hidden platform. Once they learned how to find the platform the mice were then divided into a control group, isoflurane group, and desflurane exposed groups. After exposed to their respective anesthesia, the mice would then take the MWM again (Tao et al., 2016).

During the MWM test escape latency was measured over seven days. Escape latency was determined by calculating how long it took the mice to cross platforms (Tao et al., 2016). Each day they were put in the tank the mice would remember and learn what to do and the times would improve. The data was gathered (Appendix C, Table C-2) and it was determined that escape latency times of mice treated with isoflurane for $2 \mathrm{~h}$ daily for 3 days were significantly higher than those recorded for mice that were treated only with the control group of oxygen. A two-way ANOVA test with repeated measurements found there was a significant effect on escape latency times with mice treated with isoflurane at the $\mathrm{P}<0.05$ confidence level for the conditions versus mice in the oxygen control group $[F=2.734, p=0.0153]$ (Tao et al., 2016). However, there were no significant differences in escape latency times (MWM test) with mice treated with desflurane versus the control group $[F=0.3291, p=0.9206]$ (Tao et al., 2016). The 
results determined that mice with multiple exposures to isoflurane versus multiple exposures to desflurane contributed to causing long-term spatial learning and memory impairment (Tao et al., 2016).

In the fear conditioning test (FCT) mice were placed in a chamber and allowed to roam freely (Tao et al., 2016). After three minutes a tone would sound and a mild foot shock would be administered to the mouse (Tao et al., 2016). Forty-eight hours after the initial chamber exposure, and foot shock, the mice were placed in the chamber again. During this period, referred to as a context test, the mice would be placed in the chamber, and freezing times were recorded without a tone or shock (Tao et al., 2016). Freezing times were the amount of time the mouse would stay still after the sound of the tone. This was done to determine the ability of each mouse to contextually learn that placement in this environment indicated an impending shock could be coming and the mice would freeze. During the cue test, a tone would sound and no shock would be administered. The cue or tone would signal that an impending shock was possible. Investigators recorded the time for the mice to freeze with anticipation of an incoming shock. It was noted that the isoflurane exposed mice froze less (30 seconds) during the context test, whereas desflurane and control groups remained the same (50 seconds). These findings (Appendix C, Table C-2) established that three exposures to isoflurane and not desflurane decreased the freezing times during the contextual FCT $(p=<0.01)$ (Tao et al., 2016). However, there was no change noted in any group during the cue test, with all three groups freezing for approximately 50 seconds (Tao et al., 2016).

Histological studies completed by Tao and colleagues (2016) examined the hippocampus of the mice to determine the effects isoflurane and desflurane had on 
tissues. Tao et al. were specifically concerned with how the gases effected the phosphorylation of Akt, a protein kinase, and glycogen, a synthase kinase 3B (GSK3B). These kinases play a vital role in normal brain development and memory. Phosphorylation can cause functional suppression of these kinases. By decreasing phosphorylation learning and memory formation is affected.

Using western blot analysis, Tao et al. was able to examine the amount (\%) of phosphorylation that occurred in the hippocampus of the mice. During the analysis it was determined that three exposures to isoflurane, but not desflurane, decreased the expression of these kinases by $50 \%$ when compared to the control group $(p<0.01)$. This demonstrates that multiple exposures to isoflurane affects learning and memory by increasing neurotoxicity.

Tao et al. (2016) also investigated the use of lithium as a pretreatment for the mice before isoflurane exposure to determine if it can reverse the effects on learning and memory impairment. A two-way ANOVA test found that lithium administered 30 minutes before isoflurane exposure effectively decreased escape latency times in mice treated with isoflurane compared to a group just receiving saline as a control $[F=1.741, p=0.0332]$ (Tao et al., 2016). Tao et al. (2016) also evaluated whether lithium could reverse the reduced levels of Akt, GSK3B, and Beta-actin. This experiment was conducted using three groups; a control group, an isoflurane exposed group, and a lithium pretreated isoflurane group. One-way ANOVA indicated that lithium pretreatment was able to reverse the decrease in $\mathrm{p}$-Akt $(p<0.05)$ and GSK3B $(p<0.01)$ phosphorylation suggesting that lithium can reverse isoflurane neurotoxicity.

The evaluation of the Tao et al. (2016) study using the ARRIVE guidelines determined the 
study was deficient in certain categories. There was a lack of information on how the animals were allocated to which group in the study. There was also a lack of translation and what the results would mean in the human population when exposed to the anesthetics. Tao et al. (2016) also failed to clearly define how their study was funded.

Wu, Wang, Guo, \& Zhang (2018) investigated how the NMDA receptor antagonist, ketamine, effects neuroapoptosis both by itself, and under hyperoxic conditions (Appendix B, Table B-3). Investigators also examined the effect ketamine and hyperoxia had on $\mathrm{paO}_{2}$ levels (Wu et al., 2018). The randomized control trial study used 7-day-old rat pups allocated into four groups: control, hyperoxia, ketamine, and ketamine plus hyperoxia (Wu et al., 2018). The control group was injected with saline whereas the ketamine included groups received subcutaneous injections of $50 \mathrm{mg} / \mathrm{kg}$ of ketamine. The hyperoxic group and ketamine plus hyperoxic group were exposed to higher levels of oxygen (60\%) for 2 hours (Wu et al., 2018).

The NMDA glutamate receptor is a ligand-gated ion including an NR-1 subunit that is vital to normal brain growth and development. Wu et al. (2018) aimed to determine how much ketamine would affect neuroapoptosis (Appendix C, Table C-3). Hyperoxic exposed rat pups ( $\left.\mathrm{paO}_{2} 242.3+/-12.7 \mathrm{mmHg}\right)$ and ketamine plus hyperoxic exposed rat pups $\left(\mathrm{paO}_{2} 244.7+/-9.1 \mathrm{mmHg}\right)$ demonstrated an increase in $\mathrm{paO}_{2}$ levels when compared to the control $\left(\mathrm{paO}_{2} 89.8+/-\mathrm{mmHg}\right)$ (Wu et al., 2018). Pups exposed to just hyperoxic conditions, exposure to $60 \%$ oxygen for two hours, demonstrated apoptic scores similar to the control group $(<5 \%)$. Pups exposed to ketamine without hyperoxia were found to have increased apoptosis (30\%) when compared to the control pups $(p<$ 0.01) (Wu et al., 2018). While pups exposed to ketamine with hyperoxia showed more 
apoptosis than pups receiving ketamine alone $(55 \%)(p<0.01)$ (Wu et al., 2018). The results indicate that ketamine, with or without hyperoxia, can affect expression of the NR-1 subunit which leads to an increase in neuronal apoptosis.

Using the ARRIVE guidelines to evaluate $\mathrm{Wu}$ et al. (2018) it was determined the study was deficient in two categories. Translation of the results to the human population when exposed to the anesthetics studied was not provided. Wu et al. (2018) also failed to clearly define how their study was funded. Overall, the Wu et al. (2018) study scored well in the majority of the ARRIVE guidelines created by Kilkenny et al. (2010).

The aim of the study conducted by Zheng, An, Cheng, \& Wang (2013) was to investigate whether different lengths of exposure time and different concentration percentages of the volatile inhalation agent sevoflurane affected neuronal apoptosis in 21 seven-day-old neonatal Wistar rats (Appendix B, Table B-4). The rats were randomized into five control groups. A control group, a group exposed to $1 \%$ sevoflurane for two hours, a group exposed to $1 \%$ sevoflurane for four hours, a group exposed to $2 \%$ sevoflurane for two hours, and a group exposed to $2 \%$ sevoflurane for four hours. Postanesthesia exposure subgroups were created that evaluated open-field tests and two immunohistology tests. Behavior and learning were tested at weeks five, eight, and fourteen after sevoflurane exposure.

Results related to apoptosis, behavior, and memory were tabulated (Appendix C, Table C-4). Zheng et al. (2013) used an open field technique to determine excitability. The rats were placed in a $41 \mathrm{~cm} \mathrm{x} 41 \mathrm{~cm}$ x $41 \mathrm{~cm}$ acrylic table and movements were documented at 600 seconds (Zheng et al., 2013). At 8 weeks and 14 weeks the study 
group that had been exposed to $2 \%$ sevoflurane for four hours showed an increase in movements and excitability compared to the control group $(p<0.05)$ (Zheng et al., 2013). A Morris Water Maze trail like the one used by Tao et al. (2016) showed that regardless of time duration or percentage of exposure, sevoflurane exposed rats showed no significant impairment of memory, or learning, when compared to the control group (Zheng et al., 2013).

Through Western Blot Analysis, Zheng et al. (2013) examined the cleavage of PARP-1 cells in the hippocampus of the rats. The authors found that exposure to $2 \%$ sevoflurane for four hours induces cleavage of PARP-1 in the hippocampus of exposed rats $(p<0.05)$ versus the control group. Neonatal rat exposure to even the lowest sevoflurane $1 \%$ concentration induced apoptosis (Zheng et al., 2013). Capase-3 proteases along with PARP-1 play a central role in apoptosis. The more detected in the cells of the brain the more neurodegeneration (Zheng et al., 2013). Animals treated with sevoflurane exhibited dose and time dependent neurodegeneration. Capase-3 positive cells were detected in multiple areas of the brain, with the most vulnerable area consisting of the hippocampus ( $p<0.05)$ (Zheng et al., 2013). These two immunohistology tests indicated that sevoflurane exposure at different dosage and exposure times can increase neuronal apoptosis in rats (Zheng et al., 2013).

Reviewing the Zheng et al. (2013) article using the ARRIVE guidelines created by Kilkenny et al. (2010) found that the study was deficient in just two categories. Similarly, to the $\mathrm{Wu}$ et al. (2018) study this study failed to provide how the results would translate into the human population. The study also neglected to clearly define how the 
funding for the study was achieved. Overall, the Zheng et al. (2013) study scored well in all the other ARRIVE guideline categories.

The four articles examined in this systematic review scored fairly well in all categories within the ARRIVE guidelines with results tabulated in the table located in Appendix D. All four articles scored a zero in the funding column (item 20) as no articles gave clear definition on how their studies were funded. Zheng et al. (2013), Tao et al. (2016), and Wu et al. (2018) did not provide clear evidence on how their results could be translated into the human population resulting in a score of zero in that category (item 19). O'Farrell et al. (2018) lacked a clear ethical statement (item 5) and details on the housing of the animals used for the experiment (item 9), resulting in a score of zero in those categories. Tao et al. (2016) and O'Farrell et al. (2018) failed to divulge how they chose to allocate the animals into specific study groups resulting in a score of zero for that class (item 11). Otherwise, the articles remained proficient in the remaining ARRIVE criteria created by Kilkenny et al. (2010).

The studies used for this systematic review were evaluated using Table 3 with comparison results depicted in Appendix E. This table was used to cross analyze the articles in the topics of behavioral analysis, histologic study results, and neurodegeneration results.

Within behavioral analysis it was noted by O'Farrell et al. (2018) and Zheng et al. (2013) that the anesthetics they studied, Sevoflurane and Ketamine respectfully, resulted in an increase in excitability in their subjects. Tao et al. (2016) did not find any increase in excitable activity in their subjects receiving isoflurane or desflurane; however, they did 
note issues with long-term memory impairment and learning dysfunction in those rodents exposed to isoflurane. Wu et al. (2018) did not focus on behavioral parameters in their study.

Histological analysis in all four studies uncovered an effect of anesthesia on normal functioning cells in the brain. For example, O'Farrell et al. (2018) found that during piriform cortical cell counts, there was a reduction in cells in those exposed to isoflurane and sevoflurane. Tao et al. (2016) showed a decrease in phosphorylation of Akt and GSK3B in Isoflurane exposed rats, but not in desflurane exposed rats. The Wu et al. (2018) study determined a higher mRNA and NR-1 subunit expression in those exposed to ketamine as well as ketamine + hyperoxia. Finally, Zheng et al. (2013) determined that exposure to the inhalation agent sevoflurane increased cleavage of PARP-1 in the hippocampus. Overall these studies demonstrate that based on histological findings abnormal cellular changes in the brain related to anesthesia can lead to neurodegeneration and effect neurological development.

Interestingly, the findings from O'Farrell et al. (2018) suggest that sevoflurane induces less neurotoxicity than isoflurane. The number of apoptic cells during the counts at 48 hours post exposure to sevoflurane were 1.75 micrometer versus 2.25 micrometers in isoflurane. This result is indicative of isoflurane being more deleterious to the brain than sevoflurane. Tao et al. (2016) similarly noted that isoflurane has more detrimental outcomes than that of desflurane. Isoflurane was found to cause a reduction in phosphorylation of the enzymes Akt and GSK3B, which are vital to signaling pathways linked to brain and learning development. Wu et al. 2018 indicated that ketamine with, 
and without, hyperoxia exposure increased neuroapoptosis. Apoptic cells of ketamine exposed rats increased by $35 \%$ in comparison to the control group. The Zheng et al. (2013) study determined that exposure to sevoflurane in neonatal rats induced apoptic neurodegeneration as a result of the cleavage of PARP-1 in the hippocampus.

Ultimately, the review of the cross-study analysis determined that all anesthetic modalities reviewed in these four studies had some type of adverse effect. The effects were indicated in either behavioral analysis, histologic analysis, or in some level of neurodegeneration. These results determined that exposure to certain types of anesthesia can adversely affect brain development in rodent subjects.

Next, is a discussion of the summary and conclusions. 


\section{Summary and Conclusions}

This systematic review intended to determine the effects of general anesthesia on the developing brain of children and unborn fetuses. Anesthetic agents and drugs can adversely affect the brain of children as it develops by disrupting normal neuroapoptosis. (Aker et al., 2015). Due to ethical concerns, such as brain harvesting for histological studies on the effects of anesthesia on the developing brain, randomized control trials using humans as subjects were not found. This systematic review of four random control trials provided evidence that the anesthetic agents studied: isoflurane, desflurane, sevoflurane, and intravenous ketamine, in some form or another altered normal apoptosis of rodents. As mentioned neuroapoptosis is the body's normal controlled cell death that is crucial in the role of brain development (Aker et al., 2015). Controlled cell death plays a vital role in neurodevelopment and helps to limit redundancy, faulty neurons, or unused neurons from crowding the developing brain (Creely, 2016). The effect of the neurodegeneration in these rodent studies led to the discovery of some adverse findings in learning and memory impairment, which may be equate to similar findings in humans.

The CINHAL and Pubmed databases were utilized during this systematic review. The Preferred Reporting Items for Systematic Reviews and Meta-Analyses was used to analyze, limit bias and draw accurate conclusions of the articles allocated during the database search. Critical analysis and cross study analysis were completed using the Animals in research: reporting in vivo experiments (ARRIVE) for Randomized Control trials specific to animal studies. ARRIVE utilizes a checklist and grading scale to determine articles searched meet the minimum requirements of scientific studies using animals as subjects. 
After reviewing the databases, four articles were chosen that focused on animal models which could be used to determine the effects of general anesthesia on developing brains. These studies demonstrated that volatile inhalation anesthetics, and some intravenous administrated anesthetics, currently used in anesthesia practice is linked to neurodegeneration and neurotoxicity in the developing brains of rodents.

O'Farrell et al. (2018) demonstrated that rats exposed to just one dose of the inhalation agent isoflurane produced neurologic toxicity in their piriform cortex. Both isoflurane and sevoflurane exposed rats were also found to suffer from increased activity levels and decreased suckling times. Tao et al. (2016), was able to show that exposures to isoflurane, but not desflurane, induced learning and memory impairment in mice. Tao et al. (2016) point out that this may attributed to isoflurane's effect on the Akt/GSK3ß signaling pathway, leading to neurotoxicity in the developing brain. Notably, it was further observed that lithium attenuated the effects of isoflurane, thus improving learning and memory (Tao et al., 2016).

This is similar to the cognitive effects that environmental factors, such as alcohol or lead exposure can have on brain development. While isoflurane effected memory and learning impairment in rats, alcohol has been found to act comparably in exposed fetuses (Parker et al, 2014). O'Farrell et al. (2018) noted that isoflurane exposed rats had a decrease in suckling times, which results in improper feeding, inadequate nutrition and poor development. Likewise, children and unborn fetuses who don't have adequate intake of vitamins and minerals are noted to have deficiencies in both neuronal myelination and frontal lobe development (Rothbaum et al., 2015; Young, 2012). Without the proper 
nutrition from being able to feed, the anesthesia exposed rats suffer a similar developmental disadvantage.

Wu et al. (2018) administered ketamine to seven-day-old rats under normal and hyperoxic conditions and compared this to a control group, and a hyperoxia only group. Wu et al. (2018) found that ketamine can cause abnormal neuroapoptosis in the developing rat brain, and this was further exacerbated under hyperoxic conditions. This was believed to be due to the effect of ketamine on NMDA receptor NR-1 expression (Wu et al., 2018). These findings provide evidence regarding the safety of ketamine administration alone, or under hyperoxic conditions, on the developing rat brain (Wu et al., 2018). Likewise, Ikonomidou (1999) study of seven-day-old rat pups exposed to ketamine for over 8 hours found neurological cellular degeneration and altered neuroapoptosis. Ikonomidou (1999) findings along with the results of Wu et al. (2018) indicates that the fetuses of parturient mothers, as well as infants, who receive ketamine could be subjected to neurodegeneration. However, neither study conducted a behavioral analysis on the exposed rats to determine if those traits could be translated into the human population.

Zheng et al. (2013) examined the effects of sevoflurane, at different durations, on neuronal apoptosis, development, and adaptability of exposed rats. Zheng et al. (2013) found that higher dosages and longer duration of sevoflurane led to greater neuroapoptosis in exposed rats. It was also found that exposure to sevoflurane caused an increase in excitability, however, it was noted by Zheng et al. (2013) that spatial memory and learning was not affected in the rats exposed to sevoflurane. 
The findings of Zheng et al. are in contrast to those of a retrospective study by Wilder et al. (2009). Wilder et al. determined that children exposed to not one, but multiple, doses of anesthetics were more likely to develop learning difficulties. Zheng et al. (2013) noted that more frequent and longer duration of exposure to sevoflurane affected excitability and neuroapoptosis, but not memory and learning. O' Farrell et al. (2018), however, did note memory and learning impairment with isoflurane. These results indicate that it may not just be a dose and time dependent issue with anesthesia exposure in children and infants, but the type of anesthetic agent as well.

Findings of the cross-study analysis in this systematic review revealed that two studies (O'Farrell et al., 2018; Zheng et al., 2013) demonstrated an increase in excitability in their subjects during behavioral analysis. Tao et al. (2016) noted issues with long-term memory impairment and learning dysfunction in rodents exposed to isoflurane. Similar changes in the brain leading to cognitive and behavior changes has likewise been noted in children exposed to alcohol during pregnancy (Parker et al., 2014). Comparably, environmental factors such as: mercury, radiation, or lead has also been found to reduce cognitive ability and motor skills in children (Rothbaum et al., 2015). Wu et al. (2018) did not focus on behavioral parameters during their study, which is unfortunate because behavioral analysis information regarding the behavioral effects of ketamine would be beneficial to anesthesia practice.

The histological findings synthesized in the cross-study analysis reveals that all four studies, (O’ Farrell et al., 2018; Tao et al., 2016; Wu et al., 2018; Zheng et al., 2013), uncovered an anesthesia effect on normal functioning cells in the brain. All 
histological findings show abnormal changes in the brain can lead to neurodegeneration and effect development of the brain. Due to ethical concerns cell study of the brain in children is unable to be completed. This is a limitation when trying to translate the animal study findings to that of the human population. Although the results of this review indicate strong evidence that anesthetic agents result in neurotoxicity in neonatal rodents, it is not possible to determine to what degree these results correlate to the developing human brain. Rodents develop at a much faster rate than children and the brains of humans are more complex when compared to rodents (Stiles \& Jernigan, 2010).

In conclusion, this systematic review provides evidence that rodents, such as mice and rats, exposed to various inhalation and intravenous anesthetic agents can have a negative impact on their developing brain. These unfavorable outcomes can lead to learning impairment and memory issues that could affect the rodents during their lifetime. While these articles provide evidence regarding how anesthesia can affect the developing brains of rodents, further study needs to focus on the developing brains of humans. There are significant expenses and ethical dilemmas to consider in the design of large-scale research in this topic area. Future evidence from large randomized control trials (RCTs) such as the SMART Tots, MASK, and PANDA studies will hopefully paint a clearer picture on how anesthesia affects human subjects as the brain develops.

Next, Recommendations and Implications for Advanced Nursing Practice will be presented. 


\section{Recommendations and Implications for Advanced Nursing Practice}

The field of Certified Registered Nurse Anesthetists (CRNA) is ever growing. These advanced practice nurses rely heavily on evidence-based research practices for continuing education in their area. Systematic reviews that summarize the most recent research available can be used as a tool to help advance safe practice. This information can be useful, to not only CRNAs, but for any advanced practitioner that interacts with the pediatric population. Knowing the patient's anesthesia exposure history could be beneficial. If issues with learning and memory arise this information can be used to determine the best way to treat the individual.

CRNAs that provide anesthesia to the pediatric population can take information from this review, and other studies, to determine the best type of anesthetic to administer. Even though this systematic review focused on rodent subjects the results indicate advantages and disadvantages to certain inhalation agents. For example, the study by O'Farrell et al. (2018) found that sevoflurane caused less neurotoxicity than isoflurane. Further Tao et al. (2016) determined that not only did isoflurane cause more neurotoxicity than desflurane, but that it also altered learning and memory. This evidence can better inform a provider to make a determination as to whether or not to avoid isoflurane when administering volatile inhalation agents to gravid mothers or infants.

Further studies such as the project titled, SmartTots, which look at the long-term effects of anesthesia and determine its safety are needed (O'Farrell., (2018). Several studies, however, have been conducted that have focused on anesthesia exposed children and their intelligent quotient (IQ). The Mayo Anesthesia Safety in Kids Study (MASK) 
studied the neurophysical and behavior outcomes of children after anesthesia exposure (Warner, Zaccariello, Katusic, Schroeder, Hanson, Schulte, \& Flick, 2018). The intelligent quotient did not differ significantly. Single anesthesia exposed children had IQ scores an average 0.5 points lower $(95 \% \mathrm{CI}, p=0.70)$ and multiple exposed children averaged 1.3 points lower $(95 \% \mathrm{CI}, p=0.32)$ (Warner et al., 2018). It is important to note, however, that parents of the multiple exposure children in this study stated their children exhibited problems related to executive function, behavior, and reading (Warner et al., 2018). These stated secondary outcomes from the parents should be interpreted with caution. Another study conducted by Sun, Li, Dimaggio, Byrne, Ing, Miller, \& Mcgowan (2012) called the PANDA study also reviewed IQ. This study focused on children that received anesthesia for hernia repair before age three and compared them to their siblings (Sun et al., 2012). The 28 children, aged 6 to 11 -years had no significant difference in IQ, but this study was limited by the number of pairs evaluated (Sun et al., 2012).

Current long-term studies involving human subject such as SmartTots may hold the answer to how anesthesia is practiced in the future. Additional random controlled trial studies focusing on the human pediatric patient are warranted. Future studies should be conducted comparing anesthesia modalities such as inhalation agents versus intravenous agents, or, versus regional. Evidence from such research may offer anesthesia providers a way to tailor their practice for the pediatric population. In the meantime, it is important to diligently stay educated on the newest research in this topic in order to safely administer anesthesia to this vulnerable population. 


\section{References}

Aker, J., Block, R., \& Biddle, C. (2015). Anesthesia and the developing brain. AANA Journal, 83(2), 139-147. Retrieved July 11, 2017.

Andropoulos, D. B. (2017). Effect of anesthesia on the developing brain: infant and fetus. Fetal Diagnosis and Therapy, 1-11. doi:10.1159/000475928

Bennetts, P., \& Pierce, J. (2010). Apoptosis: Understanding Programmed Cell Death for the CRNA. AANA Journal,78(3), 237-245.

Brocardo, P. S., Gil-Mohapel, J., Wortman, R., Noonan, A., Mcginnis, E., Patten, A. R., \& Christie, B. R. (2017). The Effects of Ethanol Exposure During Distinct Periods of Brain Development on Oxidative Stress in the Adult Rat Brain. Alcoholism: Clinical and Experimental Research, 41(1), 26-37. doi: 10.1111/acer.13266

Butterworth, J. F., Mackey, D. C., \& Wasnick, J. D. (2014). Morgan \& Mikhails clinical anesthesiology. New York: McGraw-Hill Education.

Chudler, E. (2015). The Brain During Development. Retrieved from http://faculty.washington.edu/chudler/neurok.html

Creeley, C. (2016). From Drug-Induced Developmental Neuroapoptosis to Pediatric Anesthetic Neurotoxicity-Where Are We Now? Brain Sciences, 6(3), 32. doi:10.3390/brainsci6030032

Garcia, P., Kolesky, S., \& Jenkins, A. (2010). General Anesthetic Actions on 
GABAA Receptors. Current Neuropharmacology,8(1), 2-9. doi:10.2174/157015910790909502

Giordano, G., \& Costa, L. G. (2012). Developmental Neurotoxicity: Some Old and New Issues. ISRN Toxicology,2012, 1-12. doi:10.5402/2012/814795

Ikonomidou, C. (1999). Blockade of NMDA Receptors and Apoptotic Neurodegeneration in the Developing Brain. Science,283(5398), 70-74. doi:10.1126/science.283.5398.70

Kilkenny, C., Browne, W., Cuthill, I. C., Emerson, M., \& Altman, D. G. (2010). Animal research: Reporting in vivo experiments: The ARRIVE guidelines. British Journal of Pharmacology, 160(7), 1577-1579. doi: 10.1111/j.14765381.2010.00872.x

McEwen, M. \& Wills, E.M. (2014). Theoretical basis for nursing. (pp. 149-152) Philadelphia: Wolters Kluwer Health/Lippincott Williams \& Wilkins

Moher, D., Liberati, A., Tetzlaff, J., Altman, DG. The PRISMA Group (2009). Preferred Reporting Items for Systematic Reviews and Meta-Analyses: The PRISMA Statement. PLoS Med 6(7): e1000097. doi:10.1371/journal.pmed1000097 
Neuman, B., \& Fawcett, J. (2009, July). Neuman Systems Model. Retrieved July 22, 2017, from http://neumanssystemsmodel.org/

O’Farrell, R. A., Foley, A. G., Buggy, D. J., \& Gallagher, H. C. (2018). Neurotoxicity of Inhalation Anesthetics in the Neonatal Rat Brain: Effects on Behavior and Neurodegeneration in the Piriform Cortex. Anesthesiology Research and Practice,2018, 1-9. doi:10.1155/2018/6376090

Parker, M. O., Evans, A. M., Brock, A. J., Combe, F. J., Teh, M., \& Brennan, C. H. (2014). Moderate alcohol exposure during early brain development increases stimulus-response habits in adulthood. Addiction Biology,21(1), 49-60. doi:10.1111/adb.12176

Reddy, S. (2012). Effect of general anesthetics on the developing brain. Journal of Anaesthesiology Clinical Pharmacology, 28(1), 6-10. doi:10.4103/09709185.92426

Rothbaum, R., Aly, H., \& Massaro, A. (2015). Fetal brain development: The role of maternal nutrition, exposures, and behaviors. Journal of Pediatric Neurology,04(01), 001-009. doi:10.1055/s-0035-1557300

Shafer, S. L., Rathmell, J. P., Flood, P., \& Stoelting, R. K. (2015). Stoelting's pharmacology and physiology in anesthetic practice. Philadelphia, PA: Wolters Kluwer Health.

Stiles, J., \& Jernigan, T. L. (2010). The Basics of Brain Development. Neuropsychology Review,20(4), 327-348. doi:10.1007/s11065-010-9148-4 
Sun, L. S., Li, G., Dimaggio, C. J., Byrne, M. W., Ing, C., Miller, T. L. K., Mcgowan, F. X. (2012). Feasibility and Pilot Study of the Pediatric Anesthesia NeuroDevelopment Assessment (PANDA) Project. Journal of Neurosurgical Anesthesiology, 24(4), 382-388. doi: 10.1097/ana.0b013e31826a0371

Tao, G., Xue, Q., Luo, Y., Li, G., Xia, Y., \& Yu, B. (2016). Isoflurane is more deleterious to developing brain than desflurane: the Role of the Akt/GSK3 $\beta$ Signaling Pathway. BioMed Research International, 2016, 1-10. doi:10.1155/2016/7919640

Vilsides, P., \& Xie, Z. (2012). Neurotoxicity of General Anesthetics: An Update. Current Pharmaceutical Design,18(38), 6232-6240. doi:10.2174/138161212803832344

Warner, D. O., Zaccariello, M. J., Katusic, S. K., Schroeder, D. R., Hanson, A. C., Schulte, P. J., Flick, R. P. (2018). Neuropsychological and Behavioral Outcomes after Exposure of Young Children to Procedures Requiring General Anesthesia. Anesthesiology, 129(1), 89-105. doi: 10.1097/aln.0000000000002232

Wilder, R., Flick, R., Sprung, J., Katusic, S., Barbaresi, W., Mickelson, C., . . Warner, D. (2009). Early Exposure to Anesthesia and Learning Disabilities in a Population-Based Birth Cohort. Survey of Anesthesiology,53(6), 267-268. doi:10.1097/sa.0b013e3181be865c

Wu, C., \& Sun, D. (2015). GABA Receptors in Brain Development, Function, and Injury. Metab Brain Disorders,30(2), 367-379. doi:10.1007/s11011-014-9560-1

Wu, C., Wang, J., Guo, X., \& Zhang, Y. (2018). Ketamine exacerbates cortical neuroapoptosis under hyperoxic conditions by upregulating expression of the N- 
methyl-D-aspartate receptor subunit NR1 in the developing rat brain. $B M C$ Anesthesiology,18(1). doi:10.1186/s12871-018-0511-y

Young, R. (2012). Nutrient and iron deficiency: Focus on fetal brain development and beyond. International Journal of Childbirth Education, 27(4), 65-69.

Zheng, S. Q., An, L. X., Cheng, X., \& Wang, Y. J. (2013). Sevoflurane causes neuronal apoptosis and adaptability changes of neonatal rats. Acta Anaesthesiologica Scandinavica,57(9), 1167-1174. doi:10.1111/aas.12163 


\section{Appendix A}

\section{PRISMA 2009 Checklist}

\begin{tabular}{|c|c|c|c|}
\hline Section/topic & $\#$ & Checklist item & $\begin{array}{l}\text { Reported } \\
\text { on page \# }\end{array}$ \\
\hline \multicolumn{3}{|l|}{ TITLE } & \\
\hline Title & 1 & $\begin{array}{l}\text { Identify the report as a systematic review, meta-analysis, or } \\
\text { both. }\end{array}$ & \\
\hline \multicolumn{3}{|l|}{ ABSTRACT } & \\
\hline $\begin{array}{l}\text { Structured } \\
\text { summary }\end{array}$ & 2 & $\begin{array}{l}\text { Provide a structured summary including, as applicable: } \\
\text { background; objectives; data sources; study eligibility criteria, } \\
\text { participants, and interventions; study appraisal and synthesis } \\
\text { methods; results; limitations; conclusions and implications of } \\
\text { key findings; systematic review registration number. }\end{array}$ & \\
\hline \multicolumn{3}{|c|}{ INTRODUCTION } & \\
\hline Rationale & 3 & $\begin{array}{l}\text { Describe the rationale for the review in the context of what is } \\
\text { already known. }\end{array}$ & \\
\hline Objectives & 4 & $\begin{array}{l}\text { Provide an explicit statement of questions being addressed with } \\
\text { reference to participants, interventions, comparisons, outcomes, } \\
\text { and study design (PICOS). }\end{array}$ & \\
\hline \multicolumn{3}{|l|}{ METHODS } & \\
\hline $\begin{array}{l}\text { Protocol and } \\
\text { registration }\end{array}$ & 5 & $\begin{array}{l}\text { Indicate if a review protocol exists, if and where it can be } \\
\text { accessed (e.g., Web address), and, if available, provide } \\
\text { registration information including registration number. }\end{array}$ & \\
\hline $\begin{array}{l}\text { Eligibility } \\
\text { criteria }\end{array}$ & 6 & $\begin{array}{l}\text { Specify study characteristics (e.g., PICOS, length of follow-up) } \\
\text { and report characteristics (e.g., years considered, language, } \\
\text { publication status) used as criteria for eligibility, giving } \\
\text { rationale. }\end{array}$ & \\
\hline $\begin{array}{l}\text { Information } \\
\text { sources }\end{array}$ & 7 & $\begin{array}{l}\text { Describe all information sources (e.g., databases with dates of } \\
\text { coverage, contact with study authors to identify additional } \\
\text { studies) in the search and date last searched. }\end{array}$ & \\
\hline Search & 8 & $\begin{array}{l}\text { Present full electronic search strategy for at least one database, } \\
\text { including any limits used, such that it could be repeated. }\end{array}$ & \\
\hline Study selection & 9 & $\begin{array}{l}\text { State the process for selecting studies (i.e., screening, eligibility, } \\
\text { included in systematic review, and, if applicable, included in the } \\
\text { meta-analysis). }\end{array}$ & \\
\hline $\begin{array}{l}\text { Data collection } \\
\text { process }\end{array}$ & & $\begin{array}{l}\text { Describe method of data extraction from reports (e.g., piloted } \\
\text { forms, independently, in duplicate) and any processes for } \\
\text { obtaining and confirming data from investigators. }\end{array}$ & \\
\hline
\end{tabular}




\begin{tabular}{|c|c|}
\hline Data items & $\begin{array}{l}11 \begin{array}{l}\text { List and define all variables for which data were sought (e.g., } \\
\text { PICOS, funding sources) and any assumptions and } \\
\text { simplifications made. }\end{array}\end{array}$ \\
\hline $\begin{array}{l}\text { Risk of bias in } \\
\text { individual } \\
\text { studies }\end{array}$ & $12 \begin{array}{l}\text { Describe methods used for assessing risk of bias of individual } \\
\text { studies (including specification of whether this was done at the } \\
\text { study or outcome level), and how this information is to be used } \\
\text { in any data synthesis. }\end{array}$ \\
\hline $\begin{array}{l}\text { Summary } \\
\text { measures }\end{array}$ & $13 \begin{array}{l}\text { State the principal summary measures (e.g., risk ratio, } \\
\text { difference in means). }\end{array}$ \\
\hline $\begin{array}{l}\text { Synthesis of } \\
\text { results }\end{array}$ & $14 \begin{array}{l}\text { Describe the methods of handling data and combining results of } \\
\text { studies, if done, including measures of consistency (e.g., } \mathrm{I}^{2} \text { ) for } \\
\text { each meta-analysis. }\end{array}$ \\
\hline
\end{tabular}

\section{PRISMA 2009 Checklist}

\begin{tabular}{|c|c|c|}
\hline Section/topic & \# Checklist item & $\begin{array}{l}\text { Reported } \\
\text { on page \# }\end{array}$ \\
\hline $\begin{array}{l}\text { Risk of bias } \\
\text { across studies }\end{array}$ & $15 \begin{array}{l}\text { Specify any assessment of risk of bias that may affect the } \\
\text { cumulative evidence (e.g., publication bias, selective reporting } \\
\text { within studies). }\end{array}$ & \\
\hline $\begin{array}{l}\text { Additional } \\
\text { analyses }\end{array}$ & $\begin{array}{l}16 \begin{array}{l}\text { Describe methods of additional analyses (e.g., sensitivity or } \\
\text { subgroup analyses, meta-regression), if done, indicating which } \\
\text { were pre-specified. }\end{array} \\
\end{array}$ & \\
\hline \multicolumn{3}{|l|}{ RESULTS } \\
\hline Study selection & $\begin{array}{l}17 \text { Give numbers of studies screened, assessed for eligibility, and } \\
\text { included in the review, with reasons for exclusions at each } \\
\text { stage, ideally with a flow diagram. }\end{array}$ & \\
\hline $\begin{array}{l}\text { Study } \\
\text { characteristics }\end{array}$ & $\begin{array}{l}18 \text { For each study, present characteristics for which data were } \\
\text { extracted (e.g., study size, PICOS, follow-up period) and } \\
\text { provide the citations. }\end{array}$ & \\
\hline $\begin{array}{l}\text { Risk of bias } \\
\text { within studies }\end{array}$ & $19 \begin{array}{l}\text { Present data on risk of bias of each study and, if available, any } \\
\text { outcome level assessment (see item 12). }\end{array}$ & \\
\hline $\begin{array}{l}\text { Results of } \\
\text { individual studies }\end{array}$ & $20 \begin{array}{l}\text { For all outcomes considered (benefits or harms), present, for } \\
\text { each study: (a) simple summary data for each intervention } \\
\text { group (b) effect estimates and confidence intervals, ideally } \\
\text { with a forest plot. }\end{array}$ & \\
\hline $\begin{array}{l}\text { Synthesis of } \\
\text { results }\end{array}$ & 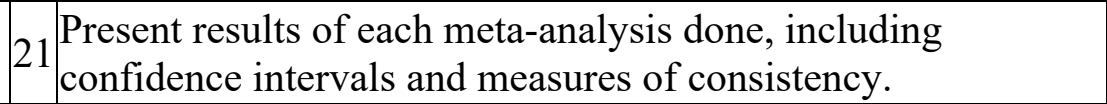 & \\
\hline $\begin{array}{l}\text { Risk of bias } \\
\text { across studies }\end{array}$ & $22 \mid \begin{array}{l}\text { Present results of any assessment of risk of bias across studies } \\
\text { (see Item 15). }\end{array}$ & \\
\hline
\end{tabular}




\begin{tabular}{|l|l|l|l|}
\hline $\begin{array}{l}\text { Additional } \\
\text { analysis }\end{array}$ & 23 & $\begin{array}{l}\text { Give results of additional analyses, if done (e.g., sensitivity or } \\
\text { subgroup analyses, meta-regression [see Item 16]). }\end{array}$ & \\
\hline DISCUSSION & 24 & $\begin{array}{l}\text { Summarize the main findings including the strength of } \\
\text { evidence for each main outcome; consider their relevance to } \\
\text { key groups (e.g., healthcare providers, users, and policy } \\
\text { makers). }\end{array}$ & \\
\hline evidence & 25 & $\begin{array}{l}\text { Discuss limitations at study and outcome level (e.g., risk of } \\
\text { bias), and at review-level (e.g., incomplete retrieval of } \\
\text { identified research, reporting bias). }\end{array}$ & \\
\hline Limitations & 26 & $\begin{array}{l}\text { Provide a general interpretation of the results in the context of } \\
\text { other evidence, and implications for future research. }\end{array}$ & \\
\hline Conclusions & 27 & $\begin{array}{l}\text { Describe sources of funding for the systematic review and } \\
\text { other support (e.g., supply of data); role of funders for the } \\
\text { systematic review. }\end{array}$ & \\
\hline FUNDING &
\end{tabular}

From: Moher D, Liberati A, Tetzlaff J, Altman DG, The PRISMA Group (2009). Preferred Reporting Items for Systematic Reviews and Meta-Analyses: The PRISMA Statement. PLoS Med 6(7): e1000097. doi:10.1371/journal.pmed1000097 


\section{Appendix B}

Table B-1

O’Farrell, R. A., Foley, A. G., Buggy, D. J., \& Gallagher, H. C. (2018). Neurotoxicity of Inhalation Anesthetics in the Neonatal Rat Brain: Effects on Behavior and Neurodegeneration in the Piriform Cortex. Anesthesiology Research and Practice,2018, 1-9. doi:10.1155/2018/6376090

\begin{tabular}{|c|c|c|c|c|}
\hline Purpose & Study Design & $\begin{array}{l}\text { Subject } \\
\text { Demographics }\end{array}$ & Methods & Measurement \\
\hline $\begin{array}{l}\text { The aim of this } \\
\text { study was to } \\
\text { determine if } \\
\text { volatile } \\
\text { inhalation } \\
\text { agents, } \\
\text { isoflurane and } \\
\text { sevoflurane, } \\
\text { cause damage } \\
\text { to the piriform } \\
\text { cortex of rat } \\
\text { pup brains as } \\
\text { much as } \\
\text { urethane. }\end{array}$ & $\begin{array}{l}\text { Random control trial } \\
\text { using animal subjects with } \\
\text { a control group. All } \\
\text { animals were either } \\
\text { administered a drug or a } \\
\text { placebo. } \\
\text { The rats were } \\
\text { administered a single dose } \\
\text { of anesthetic coinciding to } \\
\text { their assigned groups. The } \\
\text { delivery method of the } \\
\text { anesthetic was determined } \\
\text { by the preferred route of } \\
\text { the drug. Injection for } \\
\text { urethane and inhalation } \\
\text { for isoflurane and } \\
\text { sevoflurane. } \\
\text { The control group was } \\
\text { administered a placebo. }\end{array}$ & $\begin{array}{l}15 \text { Day postnatal } \\
\text { male Wistar rats. } \\
\text { 15-day-old rats } \\
\text { were used due to } \\
\text { the fact that rats } \\
\text { undergo a } \\
\text { prominent brain } \\
\text { growth spurt during } \\
\text { this period of time. }\end{array}$ & $\begin{array}{l}\text { The rats were divided into three groups. Urethane } \\
n=21 \text {, isoflurane } n=18 \text {, and sevoflurane } n=18 \\
\text { respectively. } \\
\text { The rats were tested at } 48 \text { hours and } 96 \text { hours } \\
\text { where behavior parameters were noted. After } \\
\text { testing the rat pups were sacrificed and } \\
\text { histological studies were performed to determine } \\
\text { neurotoxic effects of the anesthetic agents } \\
\text { The rats were kept normothermic through } \\
\text { warming plates during the anesthesia delivery. } \\
\text { Expired end-tidal gas analyzers were used to } \\
\text { determine the appropriate amount of gas was } \\
\text { delivered to the isoflurane ( } 2.08 \% \text { ) and } \\
\text { sevoflurane (3.4\%) groups. The control group was } \\
\text { administered urethane and saline intravenously. } \\
\text { All rat groups FiO2 was maintained at } 0.5 \text {. } \\
\text { Anesthesia was administered to each group for } \\
\text { four hours. }\end{array}$ & $\begin{array}{l}\text { Behavior analysis of neurotoxicity: } \\
\text { each group was observed in an } \\
\text { open field environment. The } \\
\text { animals were studied for } 5 \text { minutes } \\
\text { each and observations of } \\
\text { vocalization, grooming habits, and } \\
\text { locomotion/activity were noted. } \\
\text { After the open-field observations } \\
\text { the rats were returned to their } \\
\text { mothers and observed for } 30 \\
\text { minutes: maternal grooming, } \\
\text { vocalization, and suckling was } \\
\text { noted. } \\
\text { Histopathological studies: The rats } \\
\text { were euthanized using sodium } \\
\text { pentobarbitone. The piriform } \\
\text { cortex from each rat in each group } \\
\text { were then removed and sliced into } \\
6 \text { segments. Frequency of injured } \\
\text { and/or dying cells in each layer } \\
\text { were observed and counted. }\end{array}$ \\
\hline
\end{tabular}




\section{Appendix B}

Table B-2

Tao. G, Xue, Q., Luo, Y., Li, G, Xia, Y., \& Yu, B. (2016). Isoflurane is more deleterious to developing brain that desflurane: the told of AKT/GSK3ß

signaling pathway. BioMed Research International, 2016, 1-10. Doi:10.1155/2016/7919640

\begin{tabular}{|c|c|c|c|c|}
\hline Purpose & Study Design & $\begin{array}{l}\text { Subject } \\
\text { Demographics }\end{array}$ & Methods & Measurement \\
\hline $\begin{array}{l}\text { The aim of this } \\
\text { study was to } \\
\text { determine if the } \\
\text { inhalation } \\
\text { anesthetic } \\
\text { isoflurane, used } \\
\text { in pediatric } \\
\text { anesthesia, has } \\
\text { more } \\
\text { neurotoxic } \\
\text { effects than } \\
\text { desflurane. }\end{array}$ & $\begin{array}{l}\text { A Random controlled trial } \\
\text { using three groups of mice. } \\
\text { The mice were divided } \\
\text { equally among the litters to } \\
\text { minimized differences } \\
\text { associated with different } \\
\text { mothers. } \\
\text { After being subjected to their } \\
\text { respective anesthetic groups } \\
\text { the mice were subjected to } \\
\text { two experiments and brain } \\
\text { harvesting to determine the } \\
\text { effects of the anesthetics, } \\
\text { isoflurane and desflurane, on } \\
\text { spatial reasoning and } \\
\text { memory. }\end{array}$ & $\begin{array}{l}17 \text { litters for a } \\
\text { total of } 119 \text { Six- } \\
\text { day-old mice. } \\
\text { Both genders } \\
\text { utilized. } \\
\text { The mice were } \\
\text { housed at } \\
\text { constant } \\
\text { temperature with } \\
\text { access to food } \\
\text { and water. The } \\
\text { mice were reared } \\
\text { by their mother. }\end{array}$ & $\begin{array}{l}\text { The mice were divided } \\
\text { into three groups. An } \\
\text { isoflurane group, } \\
\text { desflurane group, and a } \\
\text { control group exposed } \\
\text { to only oxygen and } \\
\text { nitrogen. } \\
\text { The mice were then } \\
\text { divided as equally as } \\
\text { possible into the } \\
\text { various experiments. }\end{array}$ & $\begin{array}{l}\text { At } 31 \text { days of age/post initial anesthesia dosages, all mice were } \\
\text { placed in the Water Maze test (MWM). Escape latency times } \\
\text { to evaluate spatial learning. } \\
\text { Platform crossing times were measured during the MWM to } \\
\text { determine spatial memory in each exposure group. } \\
\text { Fear conditioning test (FCT) was used to determine fear } \\
\text { conditioned memory. The mice were subjected to a sound and a } \\
\text { mild shock. The mice were then retested using just the sound } \\
\text { and freezing times } \\
\text { were used to determine how conditioned the mice had become } \\
\text { to the fear of being potentially shocked. } \\
\text { The Freezing times were recorded to determine fear conditioned } \\
\text { memory. } \\
\text { Western blot analysis (WBA) was used to determine } \\
\text { hippocampus changes in harvested mouse brains exposed to } \\
\text { anesthesia. The amount of } \\
\text { phosphorylation of proteins associated with memory. }\end{array}$ \\
\hline
\end{tabular}




\section{Appendix B}

Table B-3

Wu, C., Wang, J., Guo, X., \& Zhang, Y. (2018). Ketamine exacerbates cortical neuroapoptosis under hyperoxic conditions by upregulating expression of the N-methyl-D-aspartate receptor subunit NR1 in the developing rat brain. BMC Anesthesiology,18(1). doi:10.1186/s12871-018-0511-y

\begin{tabular}{|c|c|c|c|c|}
\hline Purpose & Study Design & $\begin{array}{l}\text { Subject } \\
\text { Demographics }\end{array}$ & Methods & Measurement \\
\hline $\begin{array}{l}\text { The aim of this study } \\
\text { is to determine the } \\
\text { possible effects of } \\
\text { the NMDA receptor } \\
\text { antagonist Ketamine } \\
\text { and hyperoxia has on } \\
\text { the developing brain. } \\
\text { Specifically, the NR1 } \\
\text { receptor. }\end{array}$ & $\begin{array}{l}\text { Random control trial } \\
\text { using rat pup models. } \\
\text { Rats were allocated } \\
\text { into four separate } \\
\text { groups. } \\
\text { - } \\
\text { Control } \\
\text { group } \\
\text { - } \text { Ketamine } \\
\text { group } \\
\text { - } \quad \text { Hyperoxia } \\
\text { group } \\
\text { Ketamine }+ \\
\text { Hyperoxia } \\
\text { group }\end{array}$ & $\begin{array}{l}\text { Seven-day-old male } \\
\text { Sprague Dawley rat } \\
\text { pups. Average weight } \\
\text { of the pups was } 12- \\
16 \text { grams. The rats } \\
\text { were obtained by the } \\
\text { Peking University } \\
\text { Health Center Ethics } \\
\text { committee on Animal } \\
\text { Care. }\end{array}$ & $\begin{array}{l}N=72 \\
18 \text { rats per group. } \\
\text { Control group: received subcutaneous saline } \\
\text { injections. } \\
\text { Ketamine group: } 50 \mathrm{mg} / \mathrm{kg} \text { subcutaneous } \\
\text { injections at room air }(21 \%) \\
\text { Hyperoxia group: saline injections plus } 60 \% \\
\text { oxygen administration. } \\
\text { Ketamine }+ \text { Hyperoxia group: Ketamine } 50 \\
\text { mg/kg injections plus } 60 \% \text { oxygen } \\
\text { administration. } \\
\text { Oxygen was administered to provide a hyperoxic } \\
\text { state. The oxygen level was monitored } \\
\text { continuously. Humidity was maintained }>80 \% \text {. } \\
\text { Excess } \mathrm{CO}_{2} \text { was absorbed via soda lime. } \\
\text { Arterial oxygen saturation and physical } \\
\text { parameters were observed. }\end{array}$ & $\begin{array}{l}\text { Blood gas levels were obtained } \\
\text { from each group two-hours } \\
\text { after subcutaneous injections. } \\
\text { Degree of apoptosis was } \\
\text { measured using TUNEL assay } \\
\text { and polymerase chain reaction } \\
\text { (PCR). } \\
\text { Western blot analysis was used } \\
\text { to determine the amount of NR- } \\
1 \text { subunits were affected in } \\
\text { each group. }\end{array}$ \\
\hline
\end{tabular}




\section{Appendix B}

Table B-4

Zheng, S. Q., An, L. X., Cheng, X., \& Wang, Y. J. (2013). Sevoflurane causes neuronal apoptosis and adaptability changes of neonatal rats. Acta

Anaesthesiologica Scandinavica,57(9), 1167-1174. doi:10.1111/aas.12163

\begin{tabular}{|c|c|c|c|c|}
\hline Purpose & Study Design & $\begin{array}{l}\text { Subject } \\
\text { Demographics }\end{array}$ & Methods & Measurement \\
\hline $\begin{array}{l}\text { The aim of this study } \\
\text { was to determine if } \\
\text { the increase in the } \\
\text { concentration and } \\
\text { duration of } \\
\text { sevoflurane causes } \\
\text { neurodegeneration } \\
\text { and behavior changes } \\
\text { as a rat develops. }\end{array}$ & $\begin{array}{l}\text { Randomized control } \\
\text { trial of rat pups. } \\
\text { Group 1: “Con” } \\
\text { group-control } \\
\text { Group 2: Sevo1\%-2h } \\
\text { exposed to 1\% } \\
\text { sevoflurane for two } \\
\text { hrs. } \\
\text { Group 3: Sevo1\%-4h } \\
\text { exposed to 1\% } \\
\text { sevoflurane for four } \\
\text { hrs. } \\
\text { Group 4: Sevo2\%-2h } \\
\text { exposed to } 2 \% \\
\text { sevoflurane for two } \\
\text { hrs. } \\
\text { Group 5: Sevo2\%-4h } \\
\text { exposed to } 2 \% \\
\text { sevoflurane for four } \\
\text { hrs. }\end{array}$ & $\begin{array}{l}\text { Post-natal day } 7 \\
\text { Wistar Rats } \\
\text { raised by the } \\
\text { Laboratory } \\
\text { Animal Center of } \\
\text { Academy of } \\
\text { Military Medical } \\
\text { Sciences in } \\
\text { Beijing, China. }\end{array}$ & $\begin{array}{l}\text { Behavior and learning } \\
\text { were tested at weeks five, } \\
\text { eight, and fourteen after } \\
\text { sevoflurane exposure. } \\
\text { The rats were placed in an } \\
\text { acrylic box and exposed to } \\
\text { sevoflurane at different } \\
\text { concentrations and } \\
\text { duration. } \\
120 \text { rats were divided into } \\
\text { five separate groups of } \\
n=24 \text {. } \\
\text { The total gas flow was } \\
2 \mathrm{~L} / \text { min using } 100 \% \\
\text { oxygen and sevoflurane } \\
\text { was monitored using the } \\
\text { GE Dash } 4000 \text { anesthetic } \\
\text { gas monitor. }\end{array}$ & $\begin{array}{l}\text { Brain matter harvested to determine effects of } \\
\text { sevoflurane on apoptosis in the cortex and hippocampus. } \\
\text { Post anesthesia rats were randomized into } 3 \text { subgroups } \\
\text { Histopathologic analysis: } N=6 \text { perfused with } \\
\text { paraformaldehyde and exposed for } 24 \text { hrs. at } 4 \text { degrees } \\
\text { Celsius. } \\
\text { Western Blot Analysis: Cortex and hippocampus from } \\
\mathrm{n}=6 \text { rats were removed and homogenized six hours post } \\
\text { anesthesia. The segments were subjected to gel } \\
\text { electrophoresis and the bands were analyzed by the } \\
\text { software Gel-Pro analyzer to determine and neurological } \\
\text { changes. } \\
\text { Open-field test: Rats were placed on a table and } \\
\text { movements were observed for } 600 \text { seconds. } \\
\text { Morris Water Maze: Rats were placed in a pool of water } \\
\text { and seeing how long it took them to find the platform in } \\
\text { the center (latency). If unable to find the platform they } \\
\text { were guided. }\end{array}$ \\
\hline
\end{tabular}




\section{Appendix C}

\section{Table C-1}

\section{Outcome Data Collection}

O'Farrell, R. A., Foley, A. G., Buggy, D. J., \& Gallagher, H. C. (2018). Neurotoxicity of Inhalation Anesthetics in the Neonatal Rat Brain: Effects on Behavior and Neurodegeneration in the Piriform Cortex. Anesthesiology Research and Practice,2018, 1-9. doi:10.1155/2018/6376090

\begin{tabular}{|c|c|c|}
\hline Data Analysis & Results related to animal behavior & Results related to apoptosis \\
\hline $\begin{array}{l}\text { Data was entered into a } \\
\text { database using GraphPad } \\
\text { Prism v.4.0. The data was } \\
\text { examined for distribution } \\
\text { using the Kolmogorov- } \\
\text { Smirnov Test. } \\
\text { Normally distributed data } \\
\text { was compared using } \\
\text { Analysis of Variance } \\
\text { (ANOVA). } \\
\text { Data was expressed as } \\
\text { mean +/- SEM and } \\
\text { P }<0.05 \text { was deemed } \\
\text { statistically significant. }\end{array}$ & $\begin{array}{l}\text { No significant change in activity/locomotion, rearing, and suckling scores at } 48 \text { hours, but some } \\
\text { changes noted at } 96 \text { hours for both sevoflurane and isoflurane exposed animals. } \\
\text { Activity/Locomotion: increased in activity after exposure. } \\
\text { Sevoflurane score } 11.7 \text { at } 48 \text { hours versus } 9.9 \text { for control }(p=0.03) \text {. Score of } 15.8 \text { at } 96 \text { hours } \\
\text { versus control ( } p=0.02 \text { ). } \\
\text { Isoflurane score } 9.38 \text { at } 48 \text { hours versus } 9.9 \text { for control }(p=0.03) \text {. Score of } 15.4 \text { at } 96 \text { hours } \\
\text { versus control }(p=0.02) \text {. } \\
\text { Rearing: increased post exposure } \\
\text { Sevoflurane score } 6.78 \text { at } 48 \text { hours versus } 2.60 \text { for control. Score of } 7.56 \text { at } 96 \text { hours versus } \\
\text { control. ( } p=0.04) \\
\text { Isoflurane score } 3.38 \text { at } 48 \text { hours versus } 2.60 \text { for control. Score of } 4.25 \text { at } 96 \text { hours versus control. } \\
(p=0.04) \\
\text { Suckling: decreased post exposure } \\
\text { Sevoflurane score } 1.67 \text { at } 48 \text { hours versus } 3.20 \text { for control. Score of } 0.89 \text { at } 96 \text { hours versus } \\
\text { control. ( } p=0.04) \\
\text { Isoflurane score } 2.63 \text { at } 48 \text { hours versus } 3.20 \text { for control. Score of } 1.13 \text { at } 96 \text { hours versus control. } \\
(p=0.04)\end{array}$ & $\begin{array}{l}\text { Piriform cell counts: } \\
\text { Apoptic cell counts increased in } \\
\text { urethane and isoflurane exposed } \\
\text { rats. Sevoflurane exposed rats } \\
\text { showed little difference compared to } \\
\text { placebo. Counts were done using a } \\
\text { mean } \pm \text { SEM value. } \\
\text { Statistically significant reduction in } \\
\text { total piriform cell counts versus } \\
\text { control (sevoflurane and isoflurane } \\
p=0.03 \text { and Urethane } p=0.02 \text { ). } \\
\text { Statistically significant increase in } \\
\text { apoptic cells versus control for } \\
\text { (isoflurane } p=0.04 \text { and Urethane } \\
p=0.03 \text { ). However minimal to no } \\
\text { change in the number of dying cells } \\
\text { found in the sevoflurane group } \\
\text { versus control group. }\end{array}$ \\
\hline
\end{tabular}




\section{Appendix C}

\section{Table C-2}

\section{Outcome Data Collection}

Tao, G., Xue, Q., Luo, Y., Li, G., Xia, Y., \& Yu, B. (2016). Isoflurane is more deleterious to developing brain than desflurane: the role of the Akt/GSK3 $\beta$ signaling pathway. BioMed Research International,2016, 1-10. doi:10.1155/2016/7919640

\begin{tabular}{|c|c|c|c|}
\hline Data Analysis & Results related to apoptosis & Results related to behavior and memory & Lithium Pretreatment \\
\hline
\end{tabular}




\section{Appendix C}

\section{Table C-3}

\section{Outcome Data Collection}

Wu, C., Wang, J., Guo, X., \& Zhang, Y. (2018). Ketamine exacerbates cortical neuroapoptosis under hyperoxic conditions by upregulating expression of the Nmethyl-D-aspartate receptor subunit NR1 in the developing rat brain. BMC Anesthesiology,18(1). doi:10.1186/s12871-018-0511-y

\begin{tabular}{|c|c|c|c|}
\hline Data Analysis & $\begin{array}{l}\text { Results related to arterial } \\
\text { oxygenation saturation }\end{array}$ & Results related to neural apoptosis & $\begin{array}{l}\text { Results related to effect on mRNA and } \\
\text { NR1 }\end{array}$ \\
\hline $\begin{array}{l}\text { All values expressed as mean }+/- \\
\text { standard deviation. Differences were } \\
\text { analyzed by Analysis of Variance } \\
\text { (ANOVA) by SPSS statistical } \\
\text { software. } \\
\text { Statistical significance was defined as } \\
p>0.05\end{array}$ & $\begin{array}{l}\text { Ketamine alone had no effect on } \\
\text { paO2. } \\
\text { Rat pups exposed to hyperoxia } \\
\text { alone had no affect to those of the } \\
\text { control group }(p>0.05) \text {. Control } \\
\text { group } \mathrm{PaO}_{2} 89 \% \text { versus } 91.5 \% \text { for } \\
\text { the } \mathrm{Ketamine} \mathrm{alone} \mathrm{group.} \\
\text { Ketamine and hyperoxia } \\
\text { together increased } \mathrm{PaO}_{2} \text {. } \\
\mathrm{PaO}_{2} \text { was increased to } 55 \% \text { from } \\
\text { the control group. }(\mathrm{p}>0.01) \text {. } \\
\text { No changes in pH, } \mathrm{SaO}_{2} \text {, or } \mathrm{PaCO}_{2} \\
\text { were noted in the four groups. }\end{array}$ & $\begin{array}{l}\text { Ketamine with and without } \\
\text { hyperoxia caused apoptosis in the } \\
\text { frontal cortex. } \\
\text { Hyperoxia alone: Rat pups } \\
\text { exposed to hyperoxia alone had } \\
\text { apoptic scores similar (around } 1 \%) \\
\text { to those of the control group }(p> \\
0.05) \text {. } \\
\text { Ketamine without hyperoxia: } \\
\text { increased amount of apoptic cell } \\
\text { death }(p>0.01) \text { around } 30 \% . \\
\text { Ketamine with hyperoxia: } \\
\text { increased amount of apoptic cell } \\
\text { death }(p>0.01) \text { around } 55 \% .\end{array}$ & $\begin{array}{l}\text { Ketamine with and without hyperoxia } \\
\text { increases the expression of mRNA and } \\
\text { NR1. NR1 increase is related to increased } \\
\text { neurotoxicity. } \\
\text { Ketamine without hyperoxia: increased } \\
\text { amount of mRNA and NR1 subunit } \\
\text { expression from } 0.3 \text { unitsin the control } \\
\text { group versus } 0.7 \text { units in the ketamine } \\
\text { alone group ( } p>0.01 \text { ). } \\
\text { Ketamine with hyperoxia: increased } \\
\text { amount of mRNA and NR1 subunit } \\
\text { expression from } 0.3 \text { units in the control } \\
\text { group versus } 1.6 \text { units in the ketamine with } \\
\text { hyperoxia (p }>0.01) \text {. } \\
\text { No affect with the hyperoxia only group } \\
\text { versus the control }(p>0.05 \text { ). }\end{array}$ \\
\hline
\end{tabular}




\section{Appendix C}

\section{Table C-4}

\section{Outcome Data Collection}

Zheng, S. Q., An, L. X., Cheng, X., \& Wang, Y. J. (2013). Sevoflurane causes neuronal apoptosis and adaptability changes of neonatal rats. Acta Anaesthesiologica Scandinavica,57(9), 1167-1174. doi:10.1111/aas.12163

\begin{tabular}{|c|c|c|c|}
\hline Data Analysis & $\begin{array}{l}\text { Results related to Respiratory } \\
\text { Compensation under Sevoflurane } \\
\text { exposure }\end{array}$ & Results related to apoptosis & $\begin{array}{l}\text { Results related to behavior and } \\
\text { memory }\end{array}$ \\
\hline $\begin{array}{l}\text { Western Blot Analysis and } \\
\text { Histopathologic studies, minimal } \\
\text { group size of } 6 \text { determined to detect } \\
\text { a difference between means of } 40 \% \\
\text { with an } 80 \% \text { power significance } \\
\text { level of } 0.05(p=0.05) \text {. } \\
\text { Data was expressed as standard } \\
\text { deviation. Difference comparison } \\
\text { was determined using Analysis of } \\
\text { Variance (ANOVA). }\end{array}$ & $\begin{array}{l}\text { Neonatal exposure to } \mathbf{2 \%} \\
\text { sevoflurane causes no significant } \\
\text { disturbance of ventilation and } \\
\text { oxygen. } \\
\text { pH levels remained within normal } \\
\text { limits for compensated acidosis for } \\
\text { 2\% sevoflurane. } \\
\text { pH } 7.34 \text { without sevoflurane. } \\
\text { pH } 7.37 \text { after 2-hour sevoflurane } \\
\text { exposure. } \\
\text { pH } 7.31 \text { after 4-hour sevoflurane } \\
\text { exposure. }\end{array}$ & $\begin{array}{l}\text { Exposure to sevoflurane causes a } \\
\text { time-dependent apoptic } \\
\text { neurodegeneration }(p<0.05) \text { in } \\
\text { hippocampus. Higher amounts of } \\
\text { Capase- } 3 \text { cells were detected. Rats } \\
\text { exposed to } 2 \% \text { sevo for } 4 \text { hours had } \\
\text { the most. Control } 13 \text { vs Sevo } 4 \text { hours } \\
18 \\
\text { Exposure to sevoflurane induces } \\
\text { cleavage of PARP- } 1 \text { in hippocampus } \\
(p<0.05) \text { increase then control } \\
\text { group. }\end{array}$ & $\begin{array}{l}\text { Exposure to sevoflurane enhances } \\
\text { excitability of the rats. } \\
\text { Rats exposed to sevo had more } \\
\text { movements than control group } \\
(p<0.05) \\
\text { Exposure to sevoflurane had no } \\
\text { significant impairment of memory } \\
\text { and learning in the rats. } \\
\text { Control group took a } 130 \mathrm{~cm} \text { path to } \\
\text { the platform during the Morris water } \\
\text { maze versus } 120 \mathrm{~cm} \text { for Sevoflurane } \\
\text { exposed }\end{array}$ \\
\hline
\end{tabular}




\section{Appendix D}

ARRIVE Grading Score

\begin{tabular}{|c|c|c|c|c|c|c|c|c|c|c|c|c|c|c|c|c|c|c|c|c|c|}
\hline References & Methodology & 1 & 2 & 3 & 4 & 5 & 6 & 7 & 8 & 9 & 10 & 11 & 12 & 13 & 14 & 15 & 16 & 17 & 18 & 19 & 20 \\
\hline \multirow{4}{*}{$\begin{array}{l}\text { Zheng et al. } \\
\text { (2013) } \\
\text { Tao et al. } \\
(2016) \\
O^{\prime} \text { Farrell et } \\
\text { al. (2018) } \\
\text { Wu et al. } \\
\text { (2018) }\end{array}$} & $\mathrm{RCT}$ & 1 & 1 & 1 & 1 & 1 & 1 & 1 & 1 & 1 & 1 & 1 & 1 & 1 & 1 & 1 & 1 & 1 & 1 & 0 & 0 \\
\hline & $\mathrm{RCT}$ & 1 & 1 & 1 & 1 & 1 & 1 & 1 & 1 & 1 & 1 & 0 & 1 & 1 & 1 & 1 & 1 & 1 & 1 & 0 & 0 \\
\hline & $\mathrm{RCT}$ & 1 & 1 & 1 & 1 & 0 & 1 & 1 & 1 & 0 & 1 & 0 & 1 & 1 & 1 & 1 & 1 & 1 & 1 & 1 & 0 \\
\hline & $\mathrm{RCT}$ & 1 & 1 & 1 & 1 & 1 & 1 & 1 & 1 & 1 & 1 & 1 & 1 & 1 & 1 & 1 & 1 & 1 & 1 & 0 & 0 \\
\hline
\end{tabular}

\section{Methodology Key}

$\underline{\text { Item }}$

1. Title

2. Abstract

3. Background

4. Objectives

5. Ethical Statement

6. Study Design

7. Experimental Procedures

8. Experimental Animals

9. Housing and Husbandry

10. Sample Size

11. Animal Group Allocation

12. Experimental Outcomes

13. Statistical Methods

14. Baseline Data

15. Numbers Analyzed

16. Outcomes and Estimation

17. Adverse Events

18. Interpretation/ Scientific Implications

19. Generalizability/Translation

20. Funding 


\section{Appendix E}

Cross-study Analysis

\begin{tabular}{|c|c|c|c|}
\hline Author/Year/Anesthetic & $\begin{array}{l}\text { Behavioral Analysis } \\
\text { Results }\end{array}$ & Histological Study Results & Neurodegeneration Results \\
\hline $\begin{array}{l}\text { O' Farrell et al. (2018) } \\
\text { (Volatile Gas) }\end{array}$ & $\begin{array}{l}\text {-Sevoflurane and isoflurane } \\
\text { enhance excitability. }\end{array}$ & $\begin{array}{l}\text {-Piriform cortical cells were counted. } \\
\text { A significant reduction in cells were } \\
\text { found in isoflurane }(p=0.04) \text { and } \\
\text { sevoflurane }(p=0.02) \text { exposed } \\
\text { groups when compared to control } \\
\text { groups. }\end{array}$ & $\begin{array}{l}\text {-Sevoflurane was found to induce less neurotoxicity } \\
\text { than isoflurane. The number of apoptic cells in } \\
\text { sevoflurane exposed rats at } 48 \text { hours post exposure } \\
\text { were } 1.75 \text { micrometer, versus } 2.25 \text { micrometers in } \\
\text { isoflurane rats. At } 6 \text { hours post exposure sevofluranre } \\
\text { rats remained at } 1 \text { micrometer versus } 2.25 \text { in those } \\
\text { exposed to isoflurane }(p<0.05) \text {. }\end{array}$ \\
\hline $\begin{array}{l}\text { Tao et al. (2016) } \\
\text { (Volatile Gas) }\end{array}$ & $\begin{array}{l}\text {-Isoflurane affected long- } \\
\text { term memory and learning; } \\
\text { desflurane did not. } \\
\text { Platform crossing times with } \\
\text { the Morris Water Maze were } \\
\text { higher in isoflurane exposed } \\
\text { rats ( } 80 \text { seconds) versus ( } 60 \\
\text { seconds) the control and } \\
\text { desflurane rat groups. }\end{array}$ & $\begin{array}{l}\text { - There was decreased } \\
\text { phosphorylation of Akt and GSK3B } \\
\text { in isoflurane exposed, but not } \\
\text { desflurane exposed rats. Desflurane } \\
\text { remained at } 100 \% \text { levels whereas } \\
\text { isoflurane dropped to approximately } \\
75 \% \text { in Akt and GSKB levels. }\end{array}$ & $\begin{array}{l}\text {-Isoflurane was found to induce more neurotoxicity } \\
\text { than desflurane. A reduction was found in Akt and } \\
\text { GSK3B enzyme levels that are used in signaling } \\
\text { pathways linked to brain development and learning. }\end{array}$ \\
\hline $\begin{array}{l}\text { Wu et al. (2018) } \\
\text { (Ketamine) }\end{array}$ & N/A & $\begin{array}{l}\text {-Higher mRNA and NR-1 subunit } \\
\text { expression in those exposed to } \\
\text { ketamine, ketamine + hyperoxia. }\end{array}$ & $\begin{array}{l}\text {-Ketamine with, and without, hyperoxia exposure } \\
\text { increases neuroapoptosis. Apoptic cells of Ketamine } \\
\text { exposed rats increased } 35 \% \text { versus the control group. } \\
\text { Ketamine + hyperoxia exposure increased the amount } \\
\text { of apoptic cells to } 55 \% \text { above the control group. }\end{array}$ \\
\hline $\begin{array}{l}\text { Zheng et al. (2013) } \\
\text { (Volatile Gas) }\end{array}$ & $\begin{array}{l}\text {-Sevoflurane enhances } \\
\text { excitability. More } \\
\text { movements were found in } \\
\text { flat plane and vertical plane } \\
\text { with sevoflurane exposure } \\
(p<0.05) .\end{array}$ & $\begin{array}{l}\text {-Sevoflurane exposure increases } \\
\text { cleavage of PARP- } 1 \text { in the } \\
\text { hippocampus. } 1.2 \text { Beta Lactin versus } \\
0.7 \text { in the control group }(p<0.05)\end{array}$ & $\begin{array}{l}\text { - Exposure to sevoflurane in the neonatal rat } \\
\text { induces apoptic neurodegeneration. } \\
23 \text { Capase-3 Positive Cells (apoptic cells) versus } 17 \text { in } \\
\text { the control group }(p<0.05) \text {. }\end{array}$ \\
\hline
\end{tabular}

